\title{
CULTURA MATERIAL DEL SIGLO III EN UN AMBIENTE DOMÉSTICO DE LA MESETA: EL CONJUNTO CERRADO DE LA CASA DE LOS PLINTOS DE VXAMA
}

\section{THIRD CENTURY MATERIAL CULTURE IN A DOMESTIC CONTEXT ON THE NORTH MESETA (SPAIN): THE CLOSED CONTEXT OF THE HOUSE OF PLINTHS OF VXAMA}

\author{
CARMEN GARCÍA MERINO \\ Universidad de Valladolid \\ MARGARITA SÁNCHEZ SIMÓN \\ Museo de las villas romanas (Almenara de A. Valladolid) \\ MILAGROS BURÓN ÁLVAREZ \\ Junta de Castilla y León
}

\section{RESUMEN}

En este trabajo se estudia un conjunto de materiales procedentes de una casa urbana del valle oriental del Duero construida en el siglo I, reformada después y destruida por un incendio en la segunda mitad del siglo III. Esta domus, la Casa de los plintos, situada junto al foro en la ciudad de Uxama, ha sido excavada por completo y en una de sus habitaciones, bajo una potente capa de escombros, se ha hallado un depósito inalterado correspondiente al momento de la destrucción. Consta de casi un centenar de piezas, la mayoría muy bien conservadas, donde se asocian diversas producciones cerámicas, objetos de metal, monedas, y otros elementos del mobiliario. Ese conjunto nos proporciona la imagen a escala doméstica de parte de la cultura material de esa zona de la Tarraconense durante la tercera centuria.

\section{SUMMARY}

We study here a set of finds from an urban house, the Casa de los Plintos, which has been excavated completely near the forum of the Roman town of Uxama (Osma, Soria, Spain). This house was built in the first century, remodelled later on and was destroyed in a fire in the second half of the third century. In a room below the destruction level, an unaltered deposit dating from the fire event was found; this is the set we present and study here. It consists of about one hundred objects, generally quite well preserved, with associations among ware productions, metal objects, coins and another furniture pieces. This set provides a domestic scale image of a part of the material culture in this area of the Tarraconensis during the third century.

PALABRAS CLAVE: Siglo III, producciones cerámicas, ajuar doméstico, vajilla de cocina y de mesa, arquitectura doméstica.

KEY WORDS: Third century, pottery, household, cooking and tableware, domestic architecture.

\section{INTRODUCCIÓN}

En líneas generales se puede decir que la cultura material del siglo III era prácticamente desconocida hasta hace poco más de veinte años y aún lo es en gran medida por la dificultad para identificar sus componentes en la mayoría de los contextos arqueológicos, a no ser que se disponga de términos post quem y ante quem. El hecho constatado de la circulación del numerario de bronce del siglo II, incluso del I, durante el III, unida a la perduración de las formas y tipos cerámicos altoimperiales, ha llevado durante decenios a datar inadecuadamente niveles de ocupación de esa centuria. En los últimos veinte años se han dado a conocer materiales de niveles datados fiablemente en esa época, gracias a algunos conjuntos cerrados y con el empleo de nueva metodología para el registro de la información. Los datos proceden de contadas excavaciones, realizadas algunas en villas como Vilauba (Castañer; Tremoleda; Roure 1990) y otras en medio urbano en distintas zonas de Hispania como en Turiaso (Beltrán; Paz 2004), Cartago Nova (Vidal; de Miguel 1988) y Jaca (Ona; Paz; Pérez; de Sus 1987). También se ha hecho en territorio galo en la ciudad de Vienne, por ejemplo (Leblanc; Desbat 1992), y en diversas villas y núcleos menores de población. Actualmente los trabajos sobre el medio rural son pioneros en el estudio global de esa centuria (VV.AA. 2008). 


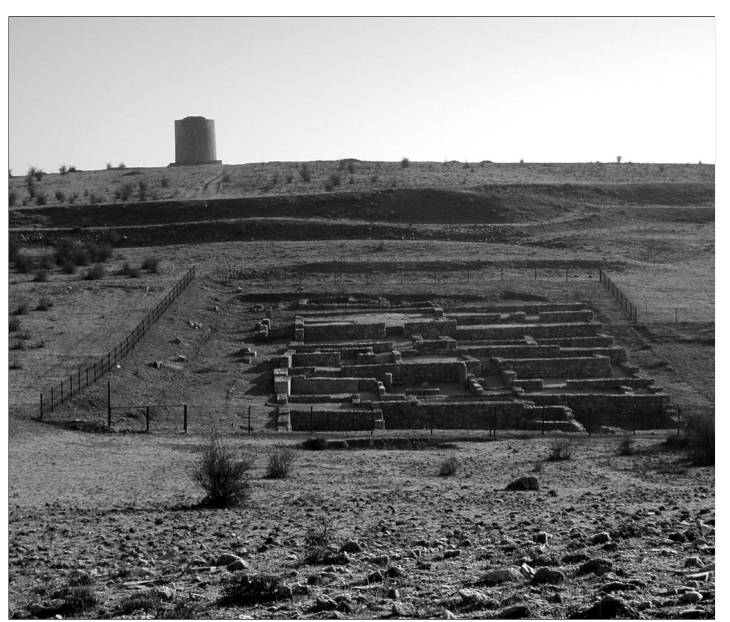

Figura 1. La Casa de los plintos vista desde el oeste.

La Casa de los plintos de Uxama, una domus del siglo III, es una de las contadas viviendas urbanas de la Meseta excavadas en la totalidad de su planta (Fig. 1) y es visitable desde el año 1997. Se han dado a conocer algunos de sus aspectos y de los materiales hallados en ella (García Merino 1990; idem 1991; idem 1995b; 1997, 100-104; García Merino; Sánchez Simón 1996; García Merino; Sánchez; Burón 2007; Gillani; Vancetti; García Merino 1994; Guerrero; Saquero; Carretero 1989), pero la casa considerada como un todo - estructuras y ajuar- permanece inédita.

\section{LA CASA DE LOS PLINTOS}

El edificio (Fig. 1) se inserta parcialmente en la trama urbana de retícula ortogonal donde se ubicó el foro (Fig. 2). Dos decumanos porticados lo enmarcan al norte y al sur mientras que por el este y el oeste lo bordean vías diagonales a las otras, quizá fruto de cambios urbanísticos posteriores. Se alzaba en una ladera que buza hacia el oeste lo que, añadido a la propia topografía accidentada de la base rocosa del terreno, ocasionaba una diferencia de altura de $5 \mathrm{~m}$ entre los extremos oriental y occidental de su planta. La pendiente se resolvía al interior de la casa con cinco niveles diferentes de solado que se bridan con duplicación o engrosamiento de muros transversales y se enlazan con escalones. Esta circunstancia ha influido decisivamente en que una de las habitaciones del norte, la número 7, haya resultado ser prácticamente un depósito sellado del momento de la destrucción del inmueble. Entre sus muros revestidos de pinturas al fresco, bajo un grueso manto de escombros y cenizas acumulados durante el incendio, se ha hallado en muy buen estado de conservación un lote de objetos que formaba parte del ajuar de la casa.

La planta (Figs. 3 y 4), inscribible en un paralelepípedo orientado de $\mathrm{E}$ a O, ocupa $920 \mathrm{~m}^{2}$ de superficie que comprenden el atrio, pasillos, cubículos, triclinios, salas, área de servicio, una cocina, dos patios — uno de ellos con un lado porticado-y un viridario, en total 24 espacios.

En esta domus de la tercera centuria destaca el hogar con fondo curvo y laterales de baldosas refractarias encastrado en la pared de una de las estancias de la fachada norte (Fig. 3, $\mathrm{n}^{\mathbf{0}} 8$ ). Casos similares hay en las Galias en Lussas-et-Nontronneau (en un nivel fechado también en el siglo III) y en Javols (Degbomont 1984, 17-19). Junto al hogar se halló un brasero rectangular de hierro con ruedas adornado con remaches de bronce (Fig. 5) (García Merino 1997, 104).

Es digno de mención también el patio del oeste (Fig. 3, no 10) con un pequeño pórtico de columnas estucadas y pintadas de rojo, un banco de piedra y una cisterna a cielo abierto. La cisterna tenía una cubierta — de madera seguramente- sobre soportes prismáticos de caliza, y una capacidad entre 10 y $15 \mathrm{~m}^{3}$ lo que sin duda supone una confortable dotación, sobre todo teniendo en cuenta que por entonces el mantenimiento del sistema público de abastecimiento de agua posiblemente estuviese en declive. Destacables son asimismo una habitación con sótano y un viridario (Fig. $3, \mathrm{n}^{\text {os }} 23$ y 24 respectivamente).

La fachada, situada en el lado norte, tiene tres puertas. La central es de $3 \mathrm{~m}$ de anchura y está enmarcada por un ensanchamiento de la acera y dos muretes con la posible función de fauces. Sobre un sillar de la zona inferior del muro, a la izquierda de la puerta principal, se representa en relieve un falo apotropaico. Una puerta secundaria, posticum, se abría al oeste en el jardín.

Los muros tienen la base de opus vittatum y el alzado de grandes adobes. En la parte baja de la fachada se han conservado dos pequeñas placas testigo de un revestimiento pintado de blanco que la cubría, color éste que también presenta alguna de las acróteras. Blanco era asimismo el color con que fueron pintados el atrio cubierto y el pasillo anejo donde una estrecha banda roja delimitaba la zona de zócalo. En el resto de la casa las paredes se adornaban con coloridos frescos encuadrables todavía en el Tercer Estilo pompeyano. De ellos se han conservado in situ algunos vestigios de zócalos que simulaban 


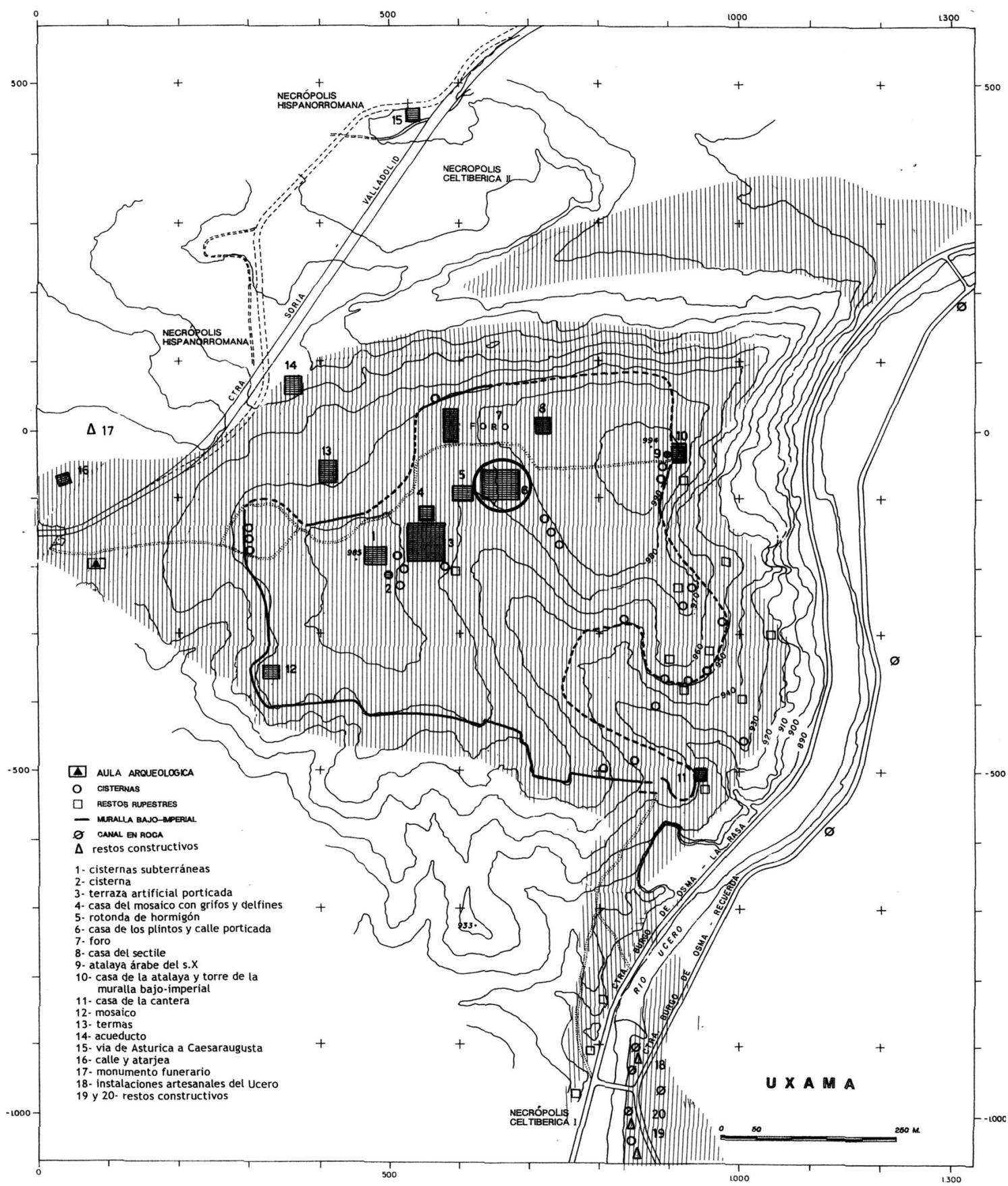

Figura 2. Situación de la Casa de los plintos en el casco urbano de Uxama (Osma, Soria).

material pétreo con salpicaduras de diversos colores sobre fondo rosado o gris. También se han recogido en las excavaciones de la zona occidental una gran cantidad de placas de los revestimientos pictóricos, con amplios paneles monocromos y frisos con decoración vegetal, animal y algunas figuras humanas.
No hay mosaicos. Los pavimentos eran en algunas de las habitaciones de baldosas y en otras de una masa muy consistente de arcilla y cal asentada sobre una capa de guijarros y detritos cerámicos que permitía sucesivas reparaciones mediante la adición de nuevas lechadas. 


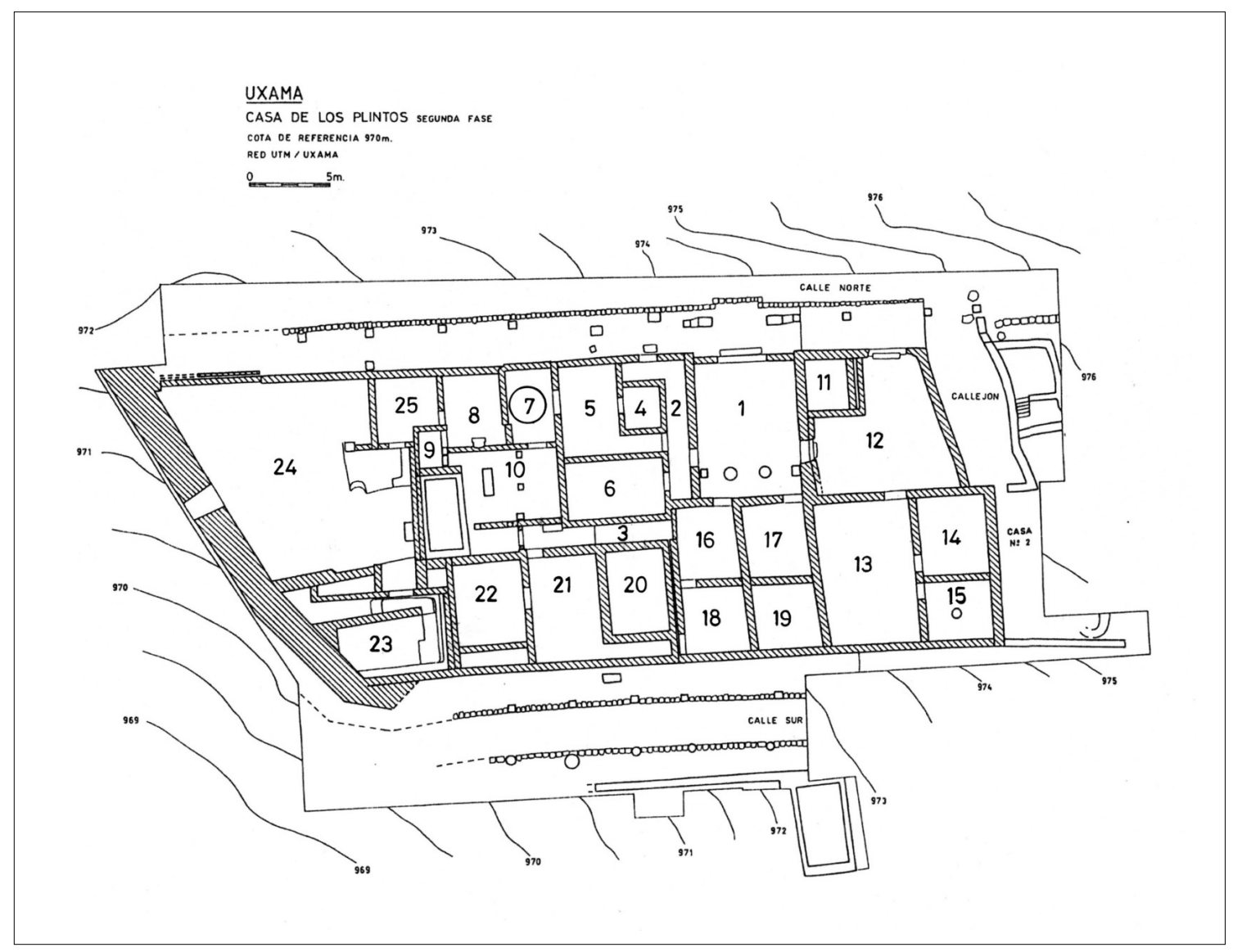

Figura 3. Plano de la Casa de los plintos con la situación del depósito cerrado.

Se han hallado algunos vidrios de ventana en la zona norte y una reja de hierro a base de una retícula de cinta plana con aspas formando estrellas de cuatro puntas en las intersecciones. Es semejante a otra procedente del mismo yacimiento (García Merino 1997, 89) y a otras de Pollentia, Conímbriga, Híspalis y Emérita. Se han recogido, asimismo, un lampadario de bronce de $1,50 \mathrm{~m}$ de altura con plato inferior sobre trípode en garras de león (García Merino 1990, 251, Lám. III y fig. 1), numerosas bisagras y herrajes de puertas y ventanas y grandes planchas de madera quemada.

El material numismático muestra una notable escasez de numerario en la que las emisiones proporcionalmente más abundantes son las de Galieno y Claudio II (García Merino 1995, 195 y 196-97). Se observan, asimismo, un predominio del gran bronce y el empleo de moneda residual, rasgos de la circulación monetaria del siglo III en la zona, como sucede en Clunia (Gurt 1985).
Esta casa tenía un largo pasado: llevaba habitada en torno a doscientos años. Su historia se ha establecido a partir de las relaciones estratigráficas y del estudio de materiales. El material numismático da luz sobre la construcción del inmueble con un término post quem: la moneda más reciente de un depósito integrado por un anillo de plata, un denario forrado de Augusto, un as de Agripa y cuatro ases de Claudio I en muy buen estado de conservación que se halló bajo el pavimento de una de las habitaciones del sur (Ibidem 192-193 y 196). También para datar la destrucción hay que recurrir a un término post quem numismático: un antoniniano de Claudio II acuñado entre 268 y 270 (García Merino 1995, 197, $\mathrm{n}^{\circ} 39$ ), documentado en una unidad estratigráfica correspondiente a la última fase de vida en la domus. La datación del incendio que lo arrasó en la segunda mitad del siglo III se refuerza con la ausencia de terra sigillata hispánica tardía entre el voluminoso conjunto de materiales recogidos en toda su 
superficie. Después del fuego el edificio no se reconstruyó, no volvió a ser habitado, posiblemente quedó convertido en un solar en ruinas, defendido por sus anchos muros perimetrales, aunque las calles que lo enmarcaban se repavimentaron sobre las cenizas y siguieron transitándose.

La Casa de los plintos o del lampadario es el resultado de las transformaciones sufridas por un viejo inmueble construido en el tercer cuarto del siglo I. El solar estaba ocupado ya desde la fase tardoceltibérica por viviendas de las que subyacen algunas estructuras subterráneas excavadas en la roca y amortizadas con rellenos. Se trazó conforme al modelo importado de casa con atrio, en este caso cubierto por adaptación al clima. Entonces (Fase I) era una vivienda de menos espacios que la del siglo III, pero más amplios, con un atrio relativamente muy grande $\left(51 \mathrm{~m}^{2}\right)$ con tres vanos al fondo que se abrían al tablino.

Un incendió que también alcanzó las calles aledañas en la primera mitad del siglo II, marcó el comienzo de la segunda etapa de la vida del edificio (Fase II) en la cual tuvieron lugar una serie de obras de reconstrucción y reformas, quizá por nuevos dueños o para satisfacer nuevas necesidades de los propietarios. Algunos de los espacios fueron modificados, agrandados, subdivididos o cambiaron de función, mientras que el atrio se conservó hasta el final. La casa se amplió hacia el oeste sobre un espacio respecto a cuyo uso anterior no se han hallado evidencias, incorporando un jardín de $141 \mathrm{~m}^{2} \mathrm{y}$ una habitación con sótano. En ese contexto de remodelaciones se realizó la reforma del pequeño peristilo (Fig. 3, no 10) que pasó a tener solamente un lado porticado, el oriental. La galería septentrional se anuló para ampliar dos habitaciones colindantes al norte y la occidental desapareció para dar cabida en su lugar a una cisterna, lo que sin duda supuso una considerable mejora. También se han documentado varias reparaciones de los solados en diferentes momentos de su existencia.

Con todo, el plano de esta casa en el siglo III no se asemeja a la planta de ninguna de las pocas conocidas altoimperiales, ni a la de las lejanas de Baetulo y Ampurias, ni a la de la más cercana Casa del acueducto de Tiermes o a las de las sólo conocidas parcialmente de Clunia. Tampoco muestra ningún parecido con las bajoimperiales. Por un lado presenta novedades, como el hogar con chimenea y tubuli en el interior de las paredes (Fig. 3, no 8), una cisterna propia y un amplio viridario, pero, por otro, es notable un cierto arcaísmo al mantener el atrio, seguramente por considerarlo símbolo de prestigio.

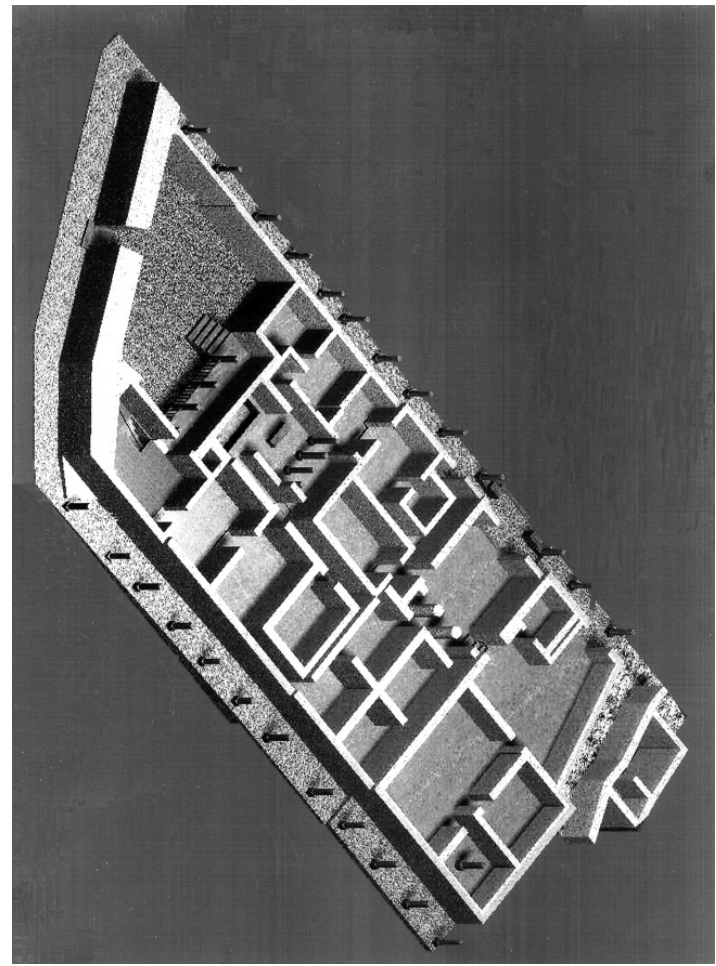

Figura 4. Restitución axonométrica de la Casa de los plintos.

También parecen claras evidencias de conservadurismo en el contexto de una tercera centuria avanzada, la predilección por el Tercer Estilo en las pinturas murales, el uso como habitáculo de un espacio excavado en la roca del subsuelo bajo la habitación de la esquina sudeste (Fig. 3, n ${ }^{\circ} 23$ ) y el empleo reiterado de un tipo de solado tradicional en algunos espacios, entre ellos el atrio. El sótano rupestre con sus claras ventajas térmicas no es infrecuente en época romana pues también se ha documentado no sólo en Uxama, por ejemplo en la coetánea Casa $n^{\circ}$ 2 (Fig. 3), sino también en inmuebles que alcanzaron una vida mas larga, como la Casa $n^{\circ} 3$ de Clunia (Palol 1994, 64 y fig. 70) y la Casa del acueducto de Tiermes (Argente et alii 1994, figs. 20-23 y Lám. $\mathrm{V})$, por no citar más que casos próximos.

\section{LA HABITACIÓN N ${ }^{\circ} 7$ DE LA CASA DE LOS PLINTOS}

Sin duda esta habitación (de 3,70/3,20 m de anchura por 5,20 m de longitud) es una de las más interesantes y mejor conservadas de toda la casa. Se localiza en la línea de la fachada entre la cocina y 


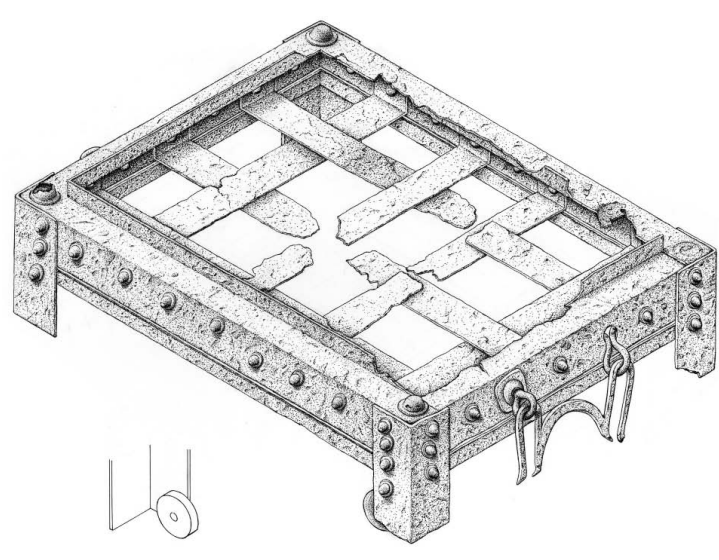

Figura 5. Brasero hallado en 1993 y utilizado en el siglo III en la Casa de los plintos. Se encontraba en la cocina en el momento del incendio.

una sala o comedor con alcoba (Fig. $3, \mathrm{n}^{\text {os }} 8$ y 5 respectivamente). A ella se accede desde esta última estancia y por el patio interior (Fig. 3, no 10).

El hecho de que el nivel de solado de la zona de la casa situada inmediatamente al este estuviese más alto que el de la habitación $n^{\circ} 7$, ha propiciado que el depósito formado durante el incendio y en la ruina inmediata haya sido en ella más potente y, por consiguiente, que su base no haya sido afectada por procesos postdeposicionales, como el expolio, la nivelación y el cultivo, que incidieron en el resto de la casa y en el yacimiento en general. Varios recipientes cerámicos se han conservado casi intactos, especialmente en el ángulo nordeste y pegados a la pared occidental. Se pudo observar que en su mayoría se encontraban en posición vertical (Fig. 6), incluso tres de ellos (Fig. 11, no 2, fig. 13, n 8 y fig. 17, $n^{\circ}$ 8) se presentaban apilados como si se hubiesen colocado en el suelo durante el incendio para llevarlos a otro lugar, pero finalmente quedasen abandonados.

Por las especiales circunstancias a que hemos aludido, la habitación $\mathrm{n}^{\circ} 7$ también conserva en $1 \mathrm{~m}$ de altura el alzado de adobe de los muros norte y oeste con la decoración pictórica. Ésta muestra un zócalo de imitación pétrea a base de salpicaduras rojas, amarillas, verdes y blancas sobre fondo rosa. Encima, pero separada por un filete blanco, aparece una zona roja en la que se alojan dos paneles ocre; en su interior una triple línea (blanco-verdeblanco), muy perdida, señala una zona de enmarque. Como elemento de separación entre ambos paneles hay un candelabro blanco con sombra gris del que quedan sólo el pie y parte del fuste. En la pared occidental únicamente se aprecian parte del zócalo,

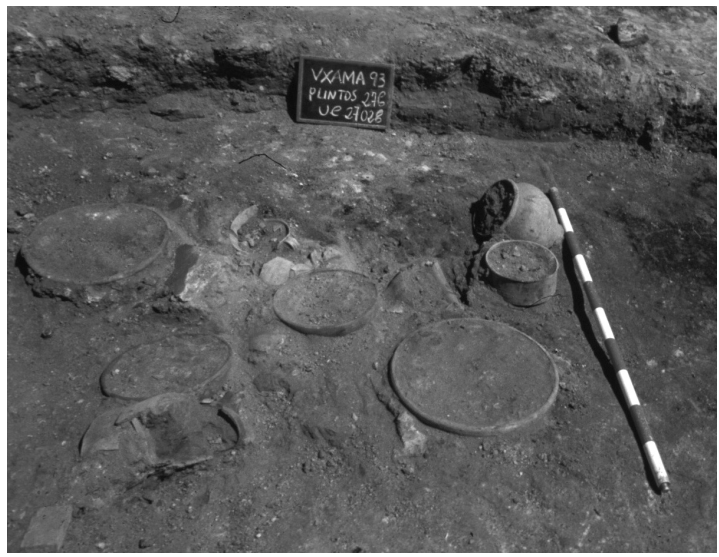

Figura 6. Aspecto parcial de la habitación n 7 durante la excavación del nivel de destrucción de la casa. Campaña de 1993. Obsérvese la dispersión de la cerámica y la posición de los recipientes.

de un cuadro y de un candelabro, lo que parece repetir la misma organización pero con 3 paneles y 2 candelabros. La parte inferior de este zócalo, relacionable con un arreglo por la reforma de la estancia, aparece ejecutada con una pincelada más gruesa en la que predomina el negro (García; Sánchez; Burón 2007).

El solado es una amalgama de cal y arcilla endurecidas sobre una capa de preparación de fragmentos cerámicos.

En lo que respecta a la estratigrafía de esta habitación ${ }^{1}$, en síntesis hay que señalar que bajo los depósitos sedimentarios formados con las tierras de arrastre de la ladera con posterioridad a la destrucción de la vivienda, se hallaron los muros de la estancia; éstos definen un espacio de 18,34 m2 construido en la Fase I, donde se han detectado algunas reformas durante la Fase II. Las paredes, como en el resto de la vivienda, muestran zócalos de opus vittatum cimentados en la roca y alzados de grandes adobes, reducidos a restos en las paredes este y sur, mientras que en la occidental y la septentrional se conservan en un metro de altura. Es significativa la traza del muro occidental en el que se aprecian dos tramos no alineados, tanto en el alzado de adobe como en la parte baja que es de piedra, de forma que describen un pequeño quiebro en el tercio meridional (Fig. 3, n ${ }^{\circ}$ ).

${ }^{1}$ Véase el estudio estratigráfico correspondiente en C. García Merino; M. Sánchez Simón: Avance a la memoria de las excavaciones de la Casa de los plintos de Uxama, Campañas de 1993 y 94. España. Comunidad Autónoma de Castilla y León. Servicio Territorial de Cultura de Soria y Dirección General de Patrimonio y Bienes Culturales de la Junta de Castilla y León en Valladolid. 


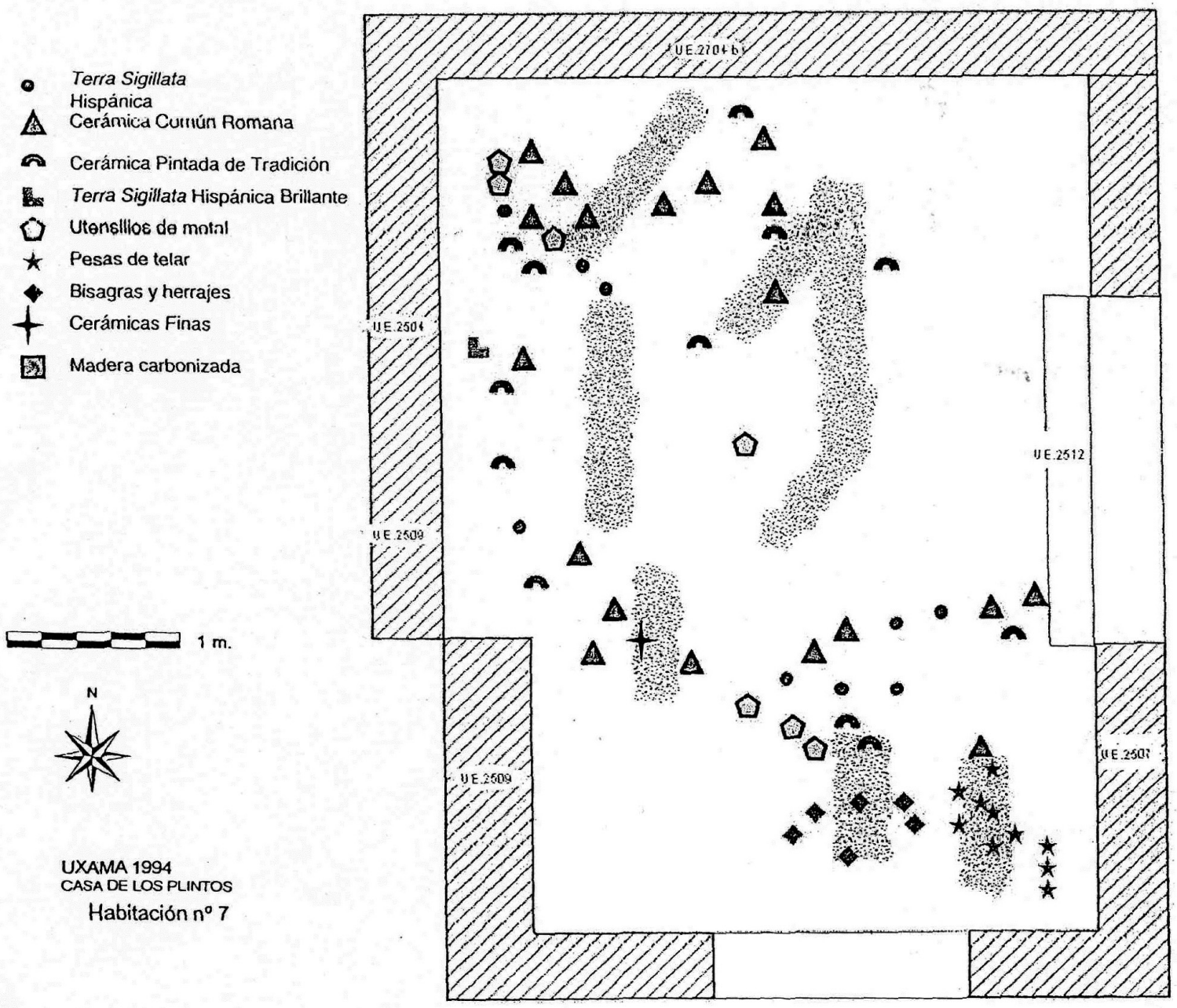

Figura 7. Situación de los diversos materiales documentados en la habitación $\mathrm{n}^{\circ} 7$ de la Casa de los plintos.

Durante la Fase I, se accedía a esta estancia desde el peristilo. El nivel de circulación estaba considerablemente más bajo que el de las habitaciones aledañas por el este. La decoración pintada de los muros en esta primera fase se ha mantenido in situ bajo los echadizos que en una fase posterior elevaron la cota de circulación.

En la Fase II se realizaron algunas reformas, como la apertura de una puerta de $2 \mathrm{~m}$ de anchura con un peldaño de $30 \mathrm{~cm}$ de altura, de lajas calizas, que comunica con la habitación $\mathrm{n}^{\circ}{ }^{\mathrm{5}}$, y el necesario recrecimiento del solado para salvar la diferencia de altura entre los niveles de circulación de ambas estancias. Para ello se dispuso sobre el solado anterior otro con una gruesa capa de preparación en el que se realizaron algunos arreglos o repavimentaciones hasta el momento del incendio final.
Sobre el último suelo un potente estrato de casi un metro de espesor se relaciona con los escombros caídos al interior de la habitación, destruida con su mobiliario por un fuerte incendio. Se compone de una matriz cenicienta, heterogénea, en la que abundan los carbones y los elementos constructivos, tales como adobes, piedras calizas, fragmentos de tejas, y trozos de revestimiento parietal. Al excavarla se halló un conjunto numeroso de vasos cerámicos, al menos 62 (en su mayor parte completos), monedas, herramientas de hierro y maderas carbonizadas de algún mueble (Fig. 7). Precisamente gracias a este nivel de derrumbe, se han preservado restos del revestimiento parietal, parte del cual pudieron ser arrancados, limpiados y consolidados los paneles norte y oeste. El panel norte, que es el mejor conservado, estuvo expuesto durante algunos años en el Aula Arqueo- 


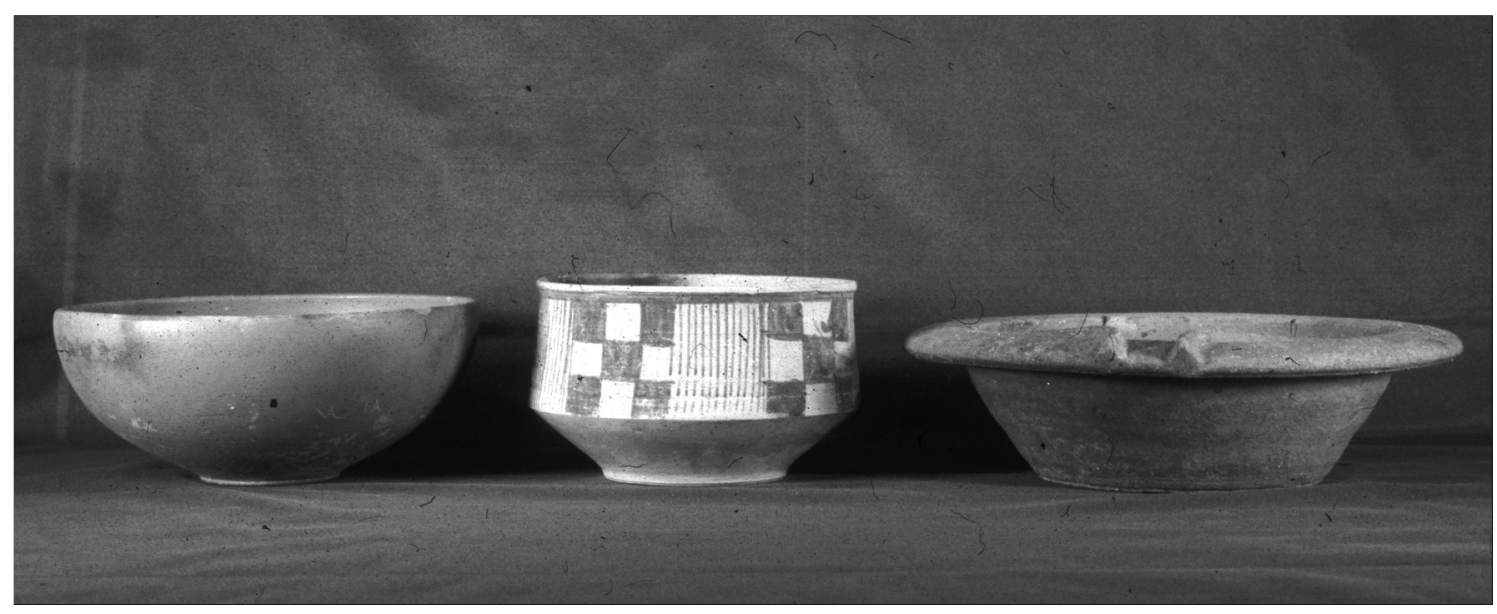

Figura. 8. Estado de conservación de los materiales de la habitación $n^{\circ}$ 7.Tres piezas representativas de la asociación de producciones cerámicas en el menaje de la casa.

lógica de Uxama y en 2006 fue trasladado al Museo Numantino (Soria).

\section{ESTUDIO DEL MATERIAL DEL NIVEL DE OCUPACIÓN / DESTRUCCIÓN DE LA FASE II DE LA HABITACIÓN 7}

Todos los materiales de variada naturaleza que se describen seguidamente aparecieron diseminados sobre el suelo de la habitación (Figs. 6 y 7). El más abundante de ellos es la cerámica (Fig. 9) en la que se asocian terra sigillata hispánica, cerámica pintada de tradición celtibérica, terra sigillata hispánica brillante, algún ejemplar de otras producciones de cerámica fina, cerámicas comunes y ánforas. Muchos de ellos estaban enteros y varios aplastados por la caída de los muros, pero completos ${ }^{2}$. El sorprendente buen estado de una parte de los primeros (Fig. 8 y fig. 21) pudo deberse a que estaban en un mueble que al volcar quedó protegiéndolos del impacto de adobes y techumbre en su caída. Se han documentado los restos carbonizados de ese mueble, estantería o armario (Fig. 7) junto con pigmento azul, diferentes clavos de hierro de pequeño tamaño y varias piezas de bisagras de hueso (Fig. 20, no 5) compuestas por cilindros de entre 2,5 y $3 \mathrm{~cm}$ de ancho con orificios circulares para encajar piezas machos y hembras de madera acoplables entre sí (Béal 1983, 101-122).

\footnotetext{
${ }^{2}$ Recientemente se ha dado a conocer una primera nota sobre este conjunto (García; Sánchez; Burón 2008)
}

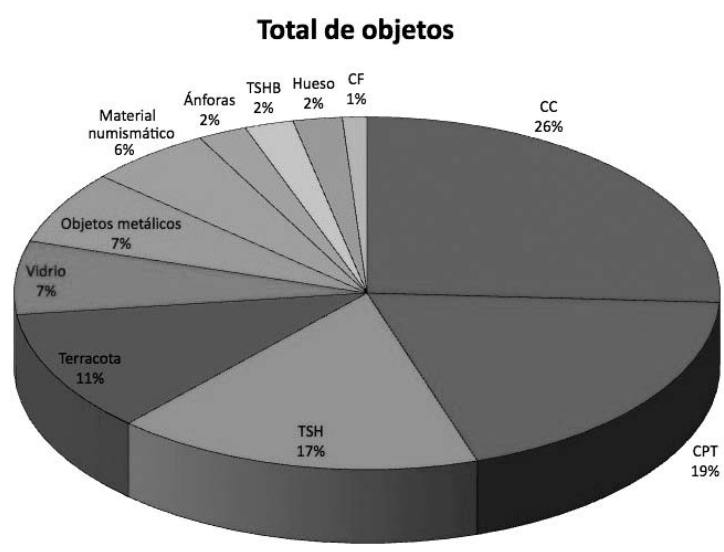

Figura 9. Porcentajes de representatividad de los diferentes materiales del ajuar de la habitación $7 . \mathrm{TSH}=$ Terra sigillata hispánica. $\mathrm{CPT}=$ Cerámica pintada de tradición. $\mathrm{CC}=$ Cerámica común. $\mathrm{CF}=$ Cerámicas finas de tipo vario. $\mathrm{TSHB}=$ Terra sigillata hispánica brillante.

\subsection{TERRA SIGILLATA HISPÁNICA (TSH)}

El elenco de piezas de TSH (Fig. 10) que se guardaban en la habitación se muestra muy homogéneo desde el punto de vista técnico y formal. Se compone de al menos 15 recipientes $^{3}$, todos ellos lisos, con predominio del cuenco hisp. 8 (con 8 ejemplares), seguido del plato hisp. 15/17 (con 3 casos), dos vasos de pared troncocónica, una hisp. 27 y una jarra de boca trilobulada. Parece claro que en el lote se distingue un servicio de mesa compuesto por el plato $15 / 17$ y el cuenco hisp. 8 de mayor tamaño.

Las piezas son similares en cuanto al color de sus pastas anaranjadas y de los barnices externos que son, 
asimismo, anaranjados y consistentes, aunque de brillo variable. El desigual grado de conservación de estos recubrimientos nos permite hablar de productos de diferente calidad. Los mejores muestran aún superficies brillantes sin pérdidas significativas del barniz (a excepción de desconchones producidos por fracturas) y éste bien adherido a la pared. En este grupo se incluyen casi todas las piezas, salvo dos cuencos hisp. 8 y la jarra que ofrecen pasta más porosa en la que el recubrimiento externo se ha conservado mal, especialmente en aquellas partes más expuestas al roce y los golpes como son las aristas y las zonas más sobresalientes.

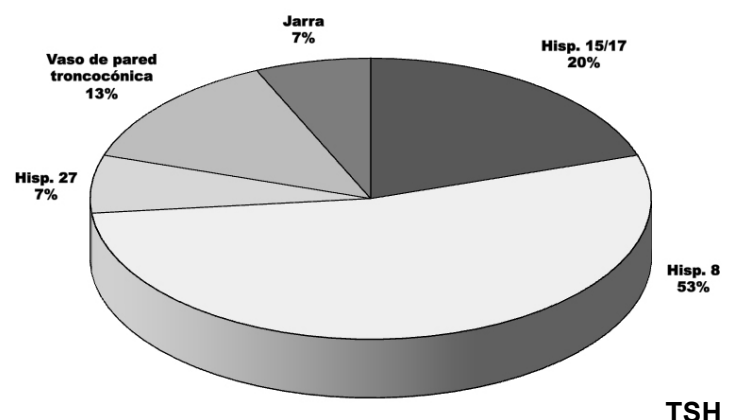

Figura. 10. Porcentajes de representatividad de formas de terra sigillata hispánica.

\section{Formas abiertas}

El recipiente que cuenta con una mayor presencia, como hemos indicado, es el cuenco hisp. 8 (Fig. $10 \mathrm{y}$ fig. $\left.11, \mathrm{n}^{\text {os }} 1-5\right)$. Morfológicamente tienen cuerpos curvos, paredes de diferentes grosores y bordes generalmente rectos con labios simples redondeados. Respecto a las bases, éstas muestran perfiles con pies bajos anulares de sección rectangular y moldura hispánica. Casi todos estos recipientes tienen un diámetro en la base con un valor comprendido entre los 5,5 y $7,5 \mathrm{~cm}$, independientemente de cuál sea la altura y amplitud de la boca. Eso significa que dentro del estándar de la producción ese es un parámetro fijo. Los restantes, altura y diámetro en la boca, ofrecen una mayor diversidad (entre 22/14 cm y $9 / 6,8 \mathrm{~cm}$ respectivamente) lo que permite hablar de recipientes más grandes o más pequeños. Sea como fuere, las proporciones indican una anchura del borde equiva-

${ }^{3}$ Se ha considerado que el número mínimo es de 15 , si bien hay restos de hasta 19 por la existencia de una base con pie poco destacado y 4 fragmentos más de bordes de la forma 8: uno con labio de sección triangular, otro engrosado al interior y otros dos de labio redondeado. Esos fragmentos no se han incluido en las figuras. lente a 2/2,5 la base. Sólo una pieza es sensiblemente más pequeña (Fig. 11, no 5 ).

Del plato hisp. $15 / 17$ sólo se hallaron 3 ejemplares, lo que quizás signifique su menor uso dentro del ajuar de mesa en esta época (Fig. $11 \mathrm{n}^{\text {os }} 6-8$ ). Sus dimensiones (bocas de 29/29,5 cm de diámetro, bases de 8,5/8,8 cm y alturas de 7,5/8, cm) y sus características técnicas son muy similares; no así los rasgos morfológicos, pues a pesar de que algunos, como los pies poco destacados de perfil triangular y moldura hispánica, que al interior ofrecen círculos incisos y también los bordes simples biselados, coinciden en las tres piezas, en la trayectoria de la pared se observan diferencias. Así, la pieza $n^{\circ} 7$ de la Fig. 11 ofrece la parte inferior recta y la pared exvasada, frente a los platos 6 y 8 de la misma ilustración que muestran una parte inferior oblicua que se prolonga hacia el borde. A pesar de ello, en todas se señala la moldura interior y la acanaladura externa en la unión base/pared. Algunos de los rasgos señalados, que como se ha dicho, conviven en las tres piezas, son propios de momentos más tempranos en su fabricación, mientras que otros son ya más evolucionados.

Asimismo formaron parte de la vajilla de mesa un vaso hisp. 27 (Fig. 11, no 9) y otros dos de perfil troncocónico (Fig. 11, nos 10 y 11), uno de ellos completo. En cuanto a estos últimos, cabe indicar que por sus paredes oblicuas y bordes redondeados podría tratarse de una variante de la forma hisp. 33, con paralelos en la villa de La Olmeda (Palol; Cortes 1974, 133) y en Beja y Lisboa procedentes de Tricio (Mayet 1984, Lám. LXVI, 122 y 123). También recuerdan a la hisp. 46, si bien algunos rasgos formales de las piezas sorianas no se ajustan exactamente a los ejemplares datados en el siglo III (Juan $2000,50)$. En cualquier caso, se trata de recipientes pequeños, más anchos que altos, para beber; con esta función se deben asociar también las piezas de vidrio y el pequeño cuenco hisp. 8. El perfil de la hisp. 27 cuenta con un borde desarrollado y un pie de sección triangular y moldura hispánica que al interior ofrecen círculos incisos, rasgos comunes a las piezas que venimos analizando. Sus dimensiones son muy similares a las del cuenco hisp. $8, \mathrm{n}^{\circ} 4$ de la Fig. 11.

\section{Formas cerradas}

Hay una sola pieza de ese tipo, una jarra pequeña de boca trilobulada (Fig. 11, $\mathrm{n}^{\mathrm{o}} 12$ ), cuello cónico recorrido por una acanaladura, cuerpo panzudo y 

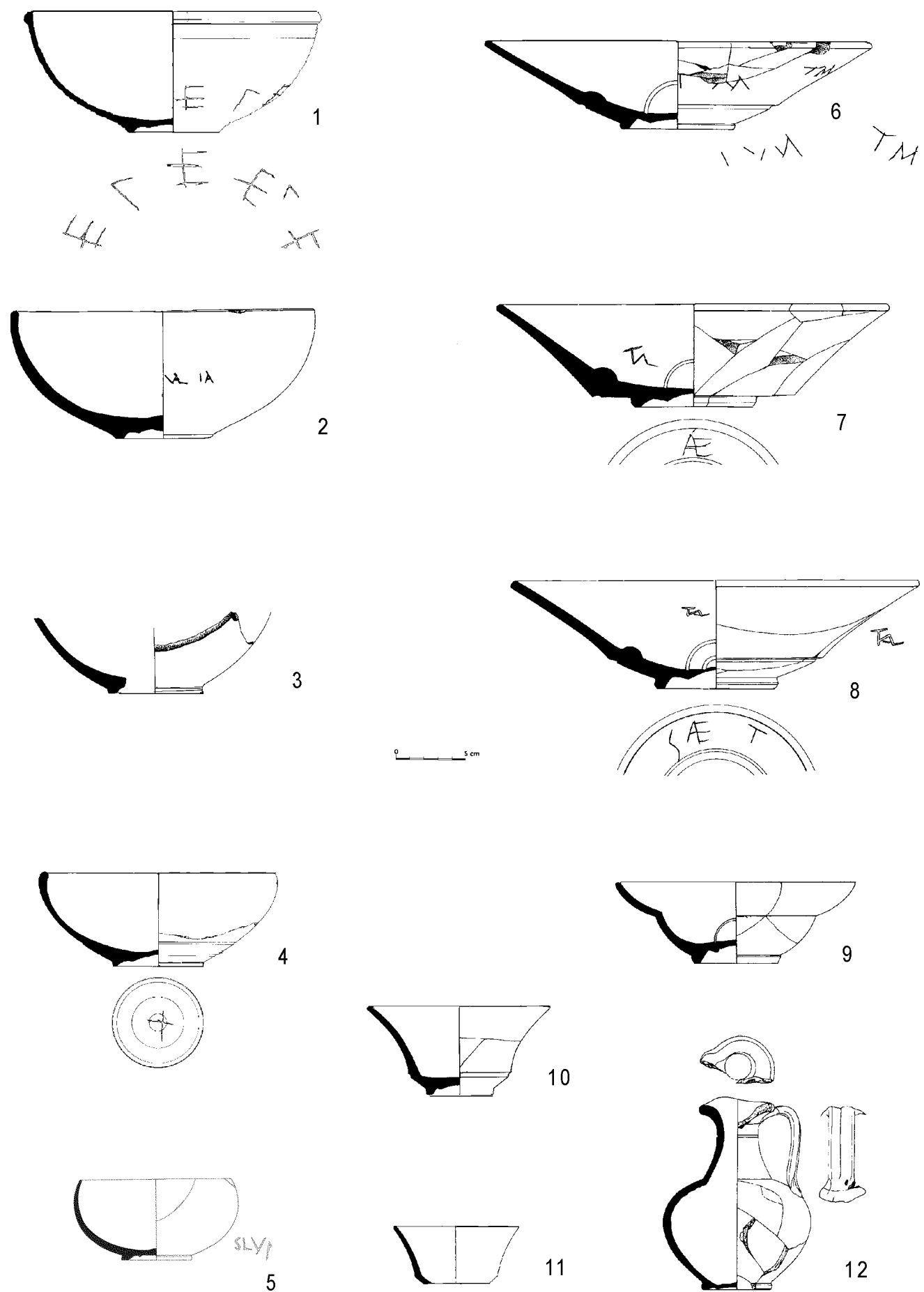

5

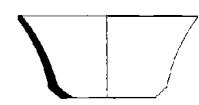

11

12

Figura 11. Habitación nº 7. Nivel de destrucción. Terra sigillata hispánica. Ver inventario.

pie destacado y moldurado. Se puede citar un paralelo que procede del yacimiento de Puente de Arce de Berantevilla, Álava (Arrizabalaga; Pérez 1994, 13-
19 Fig. 117). Es notable la reducida capacidad de esta pieza, lo que apunta a un contenido relativamente preciado como determinado vino, aceite o salsa. 
En definitiva, los rasgos técnicos y morfológicos que presentan todas estas piezas han sido señalados por diversos autores como propios de momentos avanzados en su evolución tipológica o de recipientes de contextos del siglo III d.C., y están presentes, por citar algunos ejemplos, en cerámicas de yacimientos tales como Cartagena, Clunia, Conímbriga, Jaca, Liédena, Sagunto, Tarazona y Zaragoza (Beltrán; Paz 2004; Tuset; Buxeda 1995; Delgado; Mayet; Moutinho 1975; Escrivá 1989; Juan 2000; López; Chiner 1994; Mezquíriz 1961 y 1985; Ona; Paz; Pérez y De Sus 1987; Paz 1991; Romero 1985; Vidal; De Miguel 1988).

\section{Los grafitos}

En tres de los cuencos hisp. 8 hay grafitos que en principio, salvo uno, cabe interpretar como antropónimos alusivos a los propietarios/usuarios de las piezas (Fig. 11, $\mathrm{n}^{\text {os }}$ 1, 2, 5 y 4 respectivamente). En las tres ocasiones van sobre las paredes externas y cercanos a la base. En el primero con caracteres de 2,3 $\mathrm{cm}$ de altura hay dos grupos de tres letras separados por un pequeño espacio que se distribuyen sobre el cuerpo del vaso ocupando dos terceras partes de su perímetro. Son una E con el trazo central más largo, posiblemente con fines decorativos, seguida de un signo semejante a una $\mathrm{P}$ de ojo abierto de contorno angular y de otra E. Podría leerse EPE EPE (?). Con todo, no parece referirse a una sentencia ni a nombre alguno. Es más bien incongruente. En el segundo cuenco figura en letras regulares de $0,8 \mathrm{~cm}$ de altura VAL IA con triple nexo VAL, reintegrable como Val(eri)/ae) Ia(nuarii/ae?). En un tercer ejemplar se puede leer [-]SLVP, con letras de diferente altura entre 0,8 y $1,3 \mathrm{~cm}$, aunque parecen formar una sola palabra, como cognomen resulta poco convincente; quizá mejor [-] S(ervi?) Lup/(i?). En el fondo externo de un cuarto cuenco hay otro grafito en forma de aspa.

También los tres platos 15/17 se han marcado con grafitos, dándose la circunstancia de que en dos de ellos se reproducen prácticamente los mismos antropónimos. Así, sobre la pared interna del $n^{\circ} 7$ de la Fig.11 se puede leer con cuádruple nexo en letra regular bien trazada de $1,3 \mathrm{~cm}$ de altura, T VAL, reintegrable como $T($ iti) Val(erii). Al exterior, en la base, en letra irregular mal arañada de $1,5 \mathrm{~cm}$ altura presenta el nexo AE, quizá Ae(miliii/iae?). En el no 8 de la Fig.11 en grafito interno muy bien trazado con caracteres de $1,3 \mathrm{~cm}$ de altura y cuádruple nexo, TVAL que reintegramos como el anterior $T(i t i)$
Val(erii). También este plato muestra un segundo grafito externo sobre el pie con el mismo nexo AE, aunque más completo: $\mathrm{S}$ AE $\mathrm{T}$ y, dado que el segundo de los tres elementos repite el nomen del número anterior, cabría interpretar $S(\ldots)$ Ae(milii/ae? $T(\ldots)$. Las letras de surco muy poco profundo y mal hechas tienen $1,5 \mathrm{~cm}$ de altura salvo la primera, más larga, que alcanza $2,3 \mathrm{~cm}$.

En el tercer plato el grafito contiene dos parejas de siglas separadas y a diferente altura, la primera de ellas, R M, incompleta la R, y la segunda, T M (Fig. $11, \mathrm{n}^{\circ} 6$ ), quizá interpretable como $\mathrm{T}($ iti) M(aterni?), aunque podría tratarse de cualquiera de los varios cognomina conocidos, como Mercurialis, Marcelinus, Maximus, etc.

\subsection{CerÁmica pintada de tradición (CPT)}

La proporción de piezas halladas es similar a la de la TSH (Fig.9). Se trata, sobre todo, de vajilla de mesa - vasos carenados, alguno de ellos en excelente estado de conservación (Fig. 8 y Fig. 13 no 8 ) y varios vasos bitroncocónicos- pero también de jarras y contenedores de alimentos (Fig. 12). Se han recogido en total 17 piezas, algunas fragmentadas por presión de los materiales derrumbados de la estructura de techo y paredes. Quedaron indemnes tres recipientes, en especial uno de ellos colocado sobre el pavimento, apilado con un mortero de cerámica común y un cuenco de TSH de forma 8 .

Esta variedad cerámica que hunde sus raíces en la etapa tardoceltibérica, tiene por tanto en la época de la destrucción de la Casa de los plintos una larga trayectoria que muestra entre otras cosas influencia de las formas de la cerámica romana, evidente en los vasos Abascal 23. En contraste con las producciones de los siglos I y II, ésta, más avanzada, tiende a los

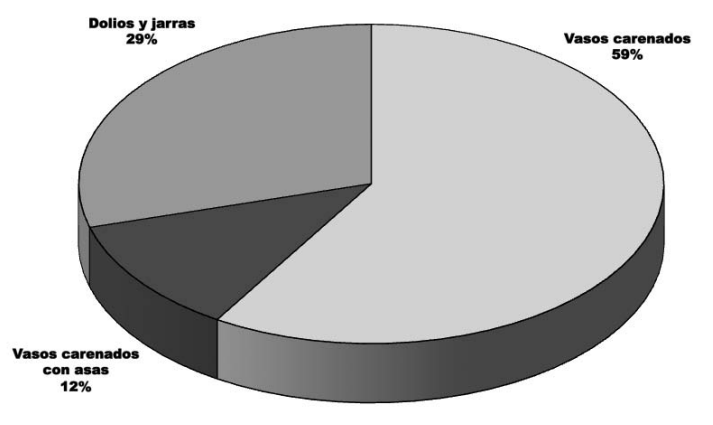

Cerámica pintada de tradición

Figura 12. Porcentajes de representatividad de formas en la cerámica pintada. 
tamaños grandes, a la simplificación de las formas y a la decoración de repertorio poco cuidada. Se emplean solamente motivos geométricos a mano alzada, sin seguir un esquema previo. Tanto los trazos como los espacios en que se divide el campo decorativo, limitado a la mitad o tercio superior de los vasos, son irregulares. Están muy lejos de los finos y cuidados motivos geométricos, vegetales y animalísticos de los siglos I y II. El estándar predominante muestra la organización del espacio decorativo en un friso dividido por haces de líneas paralelas que separan metopas donde se inscriben columnas de gruesos trazos cortos, horizontales u oblicuos, puntas de flecha o líneas onduladas, círculos o puntos que parecen aspirar a cubrir la superficie destinada a la decoración con el menor número posible de pinceladas. La realización es descuidada, especialmente en los ejemplares grandes. En las formas cerradas, delgadas bandas paralelas irregulares e, incluso, discontinuas, rodean cuello y hombros.

\section{Formas abiertas}

Vasos carenados

Esta es la forma más repetida, están torneados en pastas ocre-rosadas o levemente anaranjadas con un ligero engobe blanquecino, casi una aguada, al exterior, sobre todo por encima de la carena, zona destinada a los motivos decorativos, realizados en pintura negra clara. La mayor parte de estos vasos corresponden todavía a la forma Abascal 3a, pero evolucionada porque la relación de proporciones entre diámetro y altura es ya de 2 a 1, lo que parece un paso gradual a la forma $3 \mathrm{~b}$. Algunos tienen el labio almendrado y bajo él una estrecha banda de trazos oblicuos. La decoración se limita al espacio entre el borde y la carena en un friso en cuyas metopas hay cortos trazos más o menos horizontales o ligeramente curvos dispuestos en doble columna o en una sola hilera (Fig. 13, $\mathrm{n}^{\text {os }} 1$ y 3-5). De la forma $3 b$ hay un ejemplar de tamaño relativamente grande con decoración de ajedrezado, muy poco frecuente (Fig. 13, $\mathrm{n}^{\circ} 8$ ). Ese motivo de damero se halló también en un ejemplar del conjunto cerámico del posible alfar de Tarancueña (Soria) sobre vasos de la misma forma que se han datado como tardorromanos (Abascal 1988, 141 y 142).

En el conjunto de los 10 vasos carenados ${ }^{4}$ que se documentaron en la habitación $\mathrm{n}^{\mathrm{o}} 7$ se observan tres tamaños diferentes entre los 18,6 y los $9 \mathrm{~cm}$ de diá-

\footnotetext{
${ }^{4}$ En este trabajo presentamos sólo una selección de seis.
}

metro en la boca, distinguiéndose en función de ello 3 ejemplares grandes, 2 medianos y 2 pequeños.

Vasos bitroncocónicos con dos asas, forma Abascal 23.

Se han documentado dos ejemplares en el depósito del incendio de la habitación 7 (Fig. 13, nº 6 y 7). Otro más se halló junto a la puerta que da al patio porticado en una unidad estratigráfica equivalente. La pasta es, como en los anteriores, ocre claro con desgrasante micáceo y pequeñas intrusiones de caliza blanca y muestra un ligero engobe blanco en el exterior. Las asas son acanaladas y decoradas con dos columnas de trazos horizontales. El ejemplar menor (Fig. 13, $n^{\circ}$ 6), ofrece un esquema decorativo con paralelo en un vaso de la misma forma, hallado sobre el pavimento de la habitación 35 del complejo doméstico denominado Casa de Taracena de Clunia, y que se ha datado a mediados del siglo III (Abascal 1986a, no 741).

\section{Formas cerradas}

Tienen la pasta de iguales características que los vasos anteriores, pero de color más rosado y con más puntos calizos. Al exterior la decoración está pintada en negro claro.

\section{Cántaros y jarras}

Hay un gran cántaro de ancha boca con borde exvasado y labio recto con dos surcos al interior para asentar la tapa, y dos asas rematadas en su base por tres depresiones digitales (Fig. 14, $\mathrm{n}^{\mathrm{o}} 1$ ). Estaba cerrado, pero no con la tapadera original sino con la mitad inferior de una olla de cerámica común (Fig. $19 \mathrm{n}^{\circ}$ 6). Su pared es casi recta, abriéndose ligeramente hacia la base que le falta. No hemos encontrado paralelo a este perfil que podría estar inspirado en las formas cerradas de la cerámica común. La decoración, realizada con cierto descuido y trazos de diverso grosor e irregular trayectoria, incluye, además de las consabidas franjas de líneas horizontales y del friso, una faja de roleos y arquillos entrecruzados, combinación que aparece sobre la forma 22 en otros tres yacimientos sorianos: El Quintanar de Bayubas de Abajo, Tarancueña y Tiermes (Abascal 1986, 139).

El segundo ejemplar es un olpe o jarra asimila- 

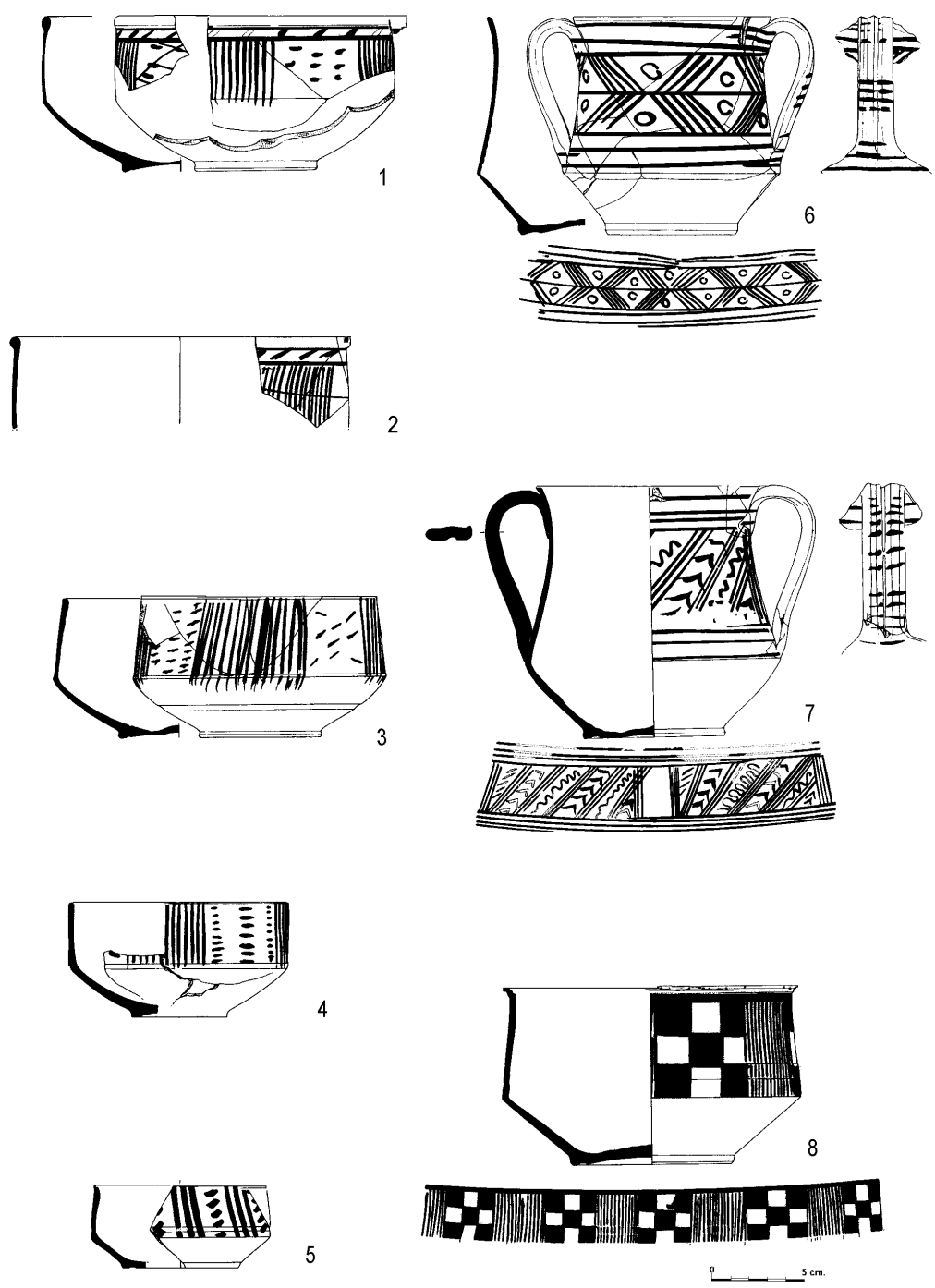

Figura 13. Habitación $n^{\circ}$ 7. Nivel de destrucción. Cerámica pintada de tradición. Ver inventario.

ble a la forma Abascal 22 del alfar de Tarancueña (Soria) (Abascal 1986,138), sin pico y más grande (Fig. $14 \mathrm{n}^{\circ}$ 3). Esta pieza de Uxama debido a sus dimensiones, mayores que la media, no sería para uso en la mesa.

\section{Contenedores de alimentos/dolios}

Son dos piezas de forma diferente. La de mayor capacidad (Fig. $15 \mathrm{n}^{\circ}$ 1) es un dolio con perfil de desarrollo cilíndrico, borde en baquetón y base con umbo central. Está decorado solamente en la zona de los hombros con una banda de metopas vacías, una franja lisa debajo de la que cuelgan a intervalos amplios haces de tres líneas curvas concéntricas. No responde a ninguna de las formas establecidas. Ligeramente parecido, sólo en cuanto al tipo de fondo, es un cántaro de Tarancueña, algo mayor, de forma 24 (Abascal 1986b,143, no 767).

El segundo ejemplar es una orza o tinajilla de pasta similar a la del recipiente anterior y perfil globular, con el borde vuelto hacia dentro (Fig. 14, $\mathrm{n}^{\mathrm{o}}$ 2), difícil de clasificar y, en todo caso, asimilable a la forma 43. Para ella en cuanto al borde hay una cierta similitud en piezas de Mérida (Abascal 1986a, $\left.\mathrm{n}^{\circ} \mathrm{s} 815-817\right)$ y una variante en Tiermes con moldura bajo la boca (Argente et alii 1994, 113, 1726). Las 

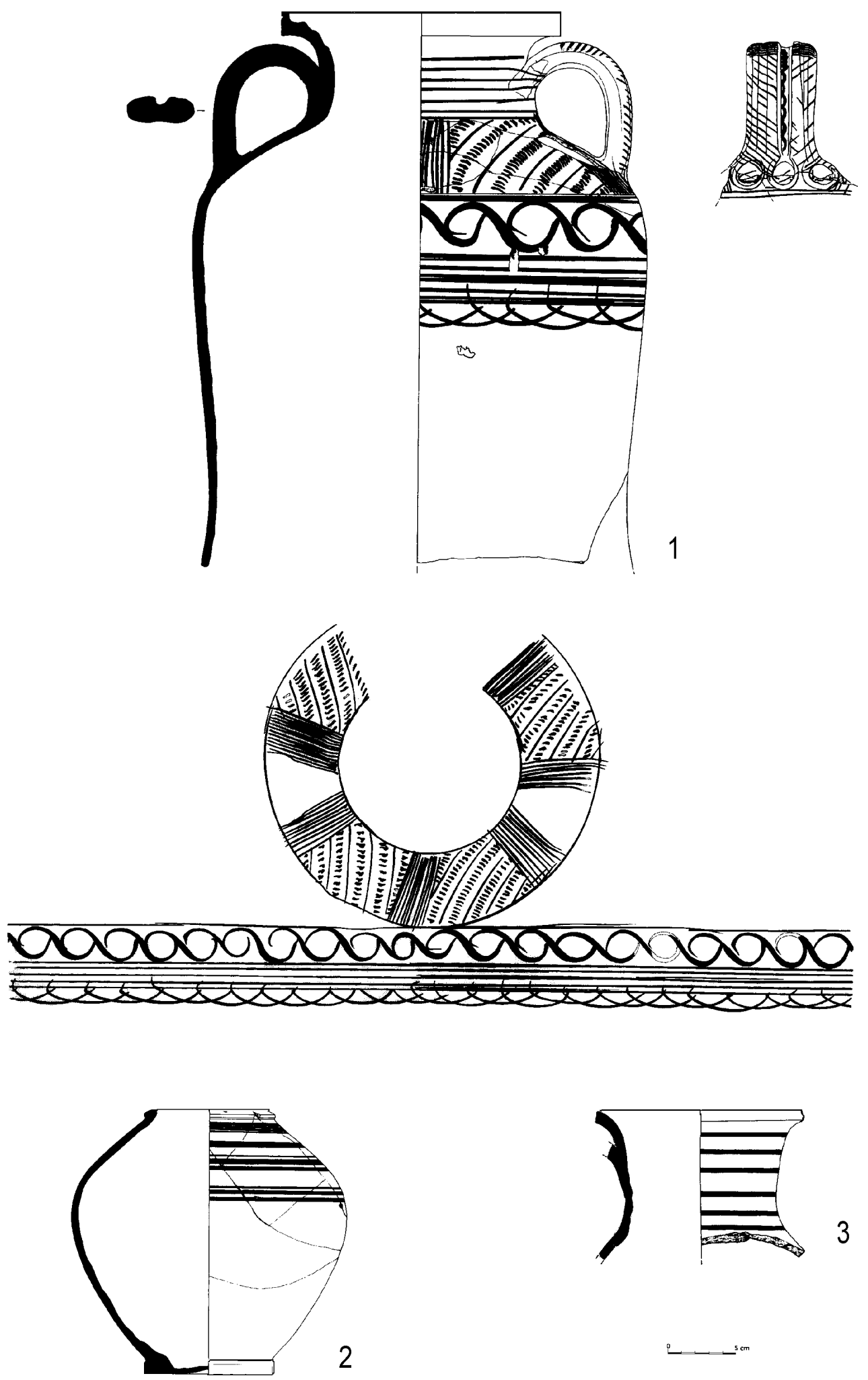

Figura 14. Habitación nº 7. Nivel de destrucción. Cerámica pintada. Ver inventario. 

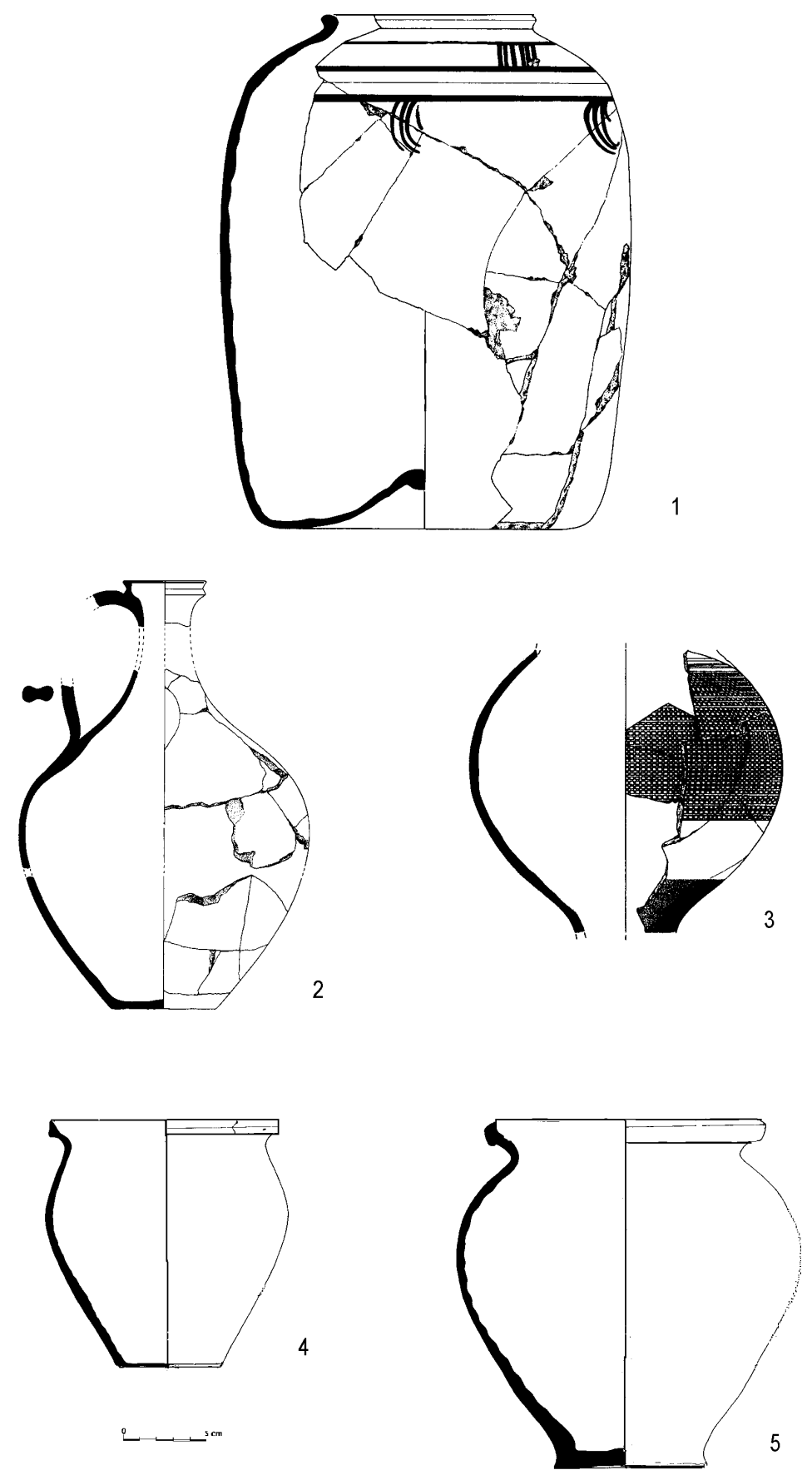

Figura 15. Habitación $\mathrm{n}^{\circ}$ 7. Nivel de destrucción. Cerámica pintada y común. Ver inventario. 
únicas piezas de perfil comparable, aunque de muy diferente funcionalidad y mucho más pequeñas y aplastadas, son dos urnitas globulares de Palencia de forma 10 (Abascal 1986a, 351, fig. 61, $\mathrm{n}^{\text {os }} 288$ y 290) y cronología altoimperial y, al parecer, con función de lucerna. En definitiva, es una forma todavía fiel a los tipos tardoceltibéricos como confirma su parecido con una vieja pieza de Ercavica considerada precedente de este tipo de cerámica en la Meseta (Abascal 1986a, fig.11, no 18). La decoración se ciñe al tercio superior. Hay una ollita completa — no la reproducimos en las láminas, pero se encuentra en la Fig. 22- de pasta semejante a la anterior, algo más pequeña con cuello estrecho y borde vuelto, un perfil que no responde a la tipología de Abascal y que más bien parece inspirado en las ollas de cerámicas grises o negras. Lleva engobe blanco y sólo conserva de la decoración pintada tres líneas horizontales en algunos puntos de la superficie situada bajo la boca.

El vaso carenado con ajedrezado, algunos otros de la misma forma y los dos bitroncocónicos con asas muestran tal similitud técnica en cuanto a la arcilla, el engobe blanco muy ligero al exterior y la propia decoración, que no sólo apuntan a un mismo taller, sino al mismo alfarero. Por la pasta también son asimilables la orza arcaizante y la ollita. Posiblemente se trate de producción local de alfares distintos a los altoimperiales que compitieron con los clunienses y que sabemos que fabricaban cerámica pintada, cerámica común y material de construcción (García Merino 1995,162; Romero et alii 2008).

\subsection{TERRA SIGILLATA HISPÁNICA BRILLANTE (TSB) Y OTRAS CERÁMICAS FINAS (CF)}

De TSHB se recuperó una jarra de la forma 15 descrita por L. Caballero y L. C. Juan que por el momento todavía está poco definida debido a la escasez de piezas halladas y a las diferencias morfológicas apreciadas (Caballero; Juan 1984, 170-171). Este ejemplar (Fig. 15, $n^{\circ}$ 2) añade una nueva variante a las vasijas publicadas por estos autores; se trata de un perfil esférico, boca pequeña, $5,7 \mathrm{~cm}$ de borde moldurado, estrecho cuello y una única asa. Realizada con pasta blanquecina, porosa y de buena calidad, su superficie externa fue recubierta con un engobe amarillo-dorado ya sin brillo. La presencia de esta pieza en el momento de la destrucción de la Casa de los plintos confirma la fecha propuesta por los citados investigadores para la prolongación de esta variedad cerámica. De morfología análoga es una pieza de Clunia del estrato Iv b del foro, aunque se la describe como de pasta clara y no se menciona engobe (Palol; Guitart 2000, 272-273).

Hay, por otra parte, una jarra de difícil clasificación. Es de barro decantado de color gris ceniciento más oscuro en la zona de la base, cuya superficie externa está alisada (Fig. 15, no 3 ). Le faltan la boca y el pie tiene la pared globular y está decorada a ruedecilla: bajo tres suaves acanaladuras que marcan la separación entre el cuello y el cuerpo aparece un friso con impresiones cuadradas poco profundas en sentido horizontal. Las características técnicas, morfológicas y decorativas de esta pieza la ponen en relación con una producción lusa de fabricación local; concretamente con el grupo 23 distinguido para las cerámicas en Conímbriga. Se trata de un conjunto datado entre el siglo i y el II d. C., cuyos antecedentes se rastrean en la denominada terra nigra (Alarção et alii 1976, 92) y que también están presentes en la necrópolis de Valdoca (Aljustrel, Portugal), cuyas fechas abarcan desde el siglo I al III (Alarção 1966, 7-104). Por el momento es imposible establecer si se trata de una imitación de los productos lusos, o si, por el contrario, es una pieza de importación.

\subsection{Cerámicas comunes (CC)}

La cerámica común ofrece una gran variedad, habiéndose encontrado en la habitación una representación de cada una de las piezas más significativas del ajuar doméstico, desde recipientes de almacenamiento hasta otros destinados al servicio y a la preparación de alimentos (Fig. 16).

La mayor parte de las piezas son de cerámica oscura, grises o negras al exterior, que formaban parte del menaje culinario, a juzgar no solo por las formas sino también por sus características técnicas: pasta

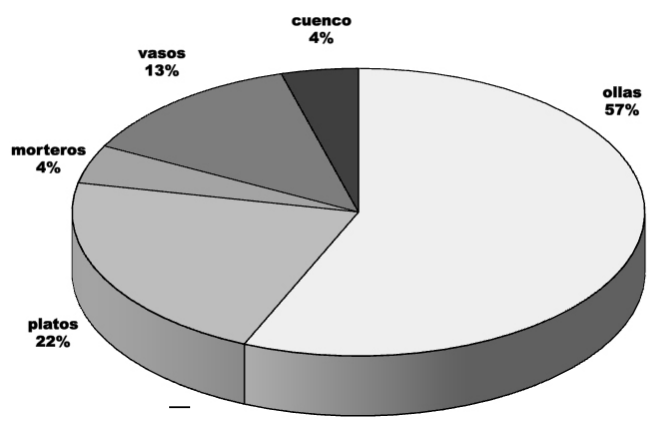

Cerámica común

Figura 16. Habitación $n^{\circ} 7$. Representatividad de formas en cerámica común. Ver inventario. 
arcillosa ocre o gris con abundante desgrasante micáceo y cocción reductora, condiciones que las hacían resistente a choques térmicos y mecánicos.

\section{Formas abiertas}

De los 5 platos, prácticamente enteros ${ }^{5}$, que se hallaron en la habitación, uno de ellos muestra indicios de haber contado con un engobe rojizo al interior, mientras que el resto lo tienen micáceo y presentan superficies fuertemente quemadas (Fig. 18, n $^{\text {os }}$ 3-5). Es de notar que en casi todos hay sobre el borde un número variable, según el diámetro de la pie$\mathrm{za}$, de pequeñas rayas incisas que a intervalos regulares marcan cuartos de círculo (ejemplo de ello es el $n^{\circ} 5$ de la Fig. 17). La finalidad de esas muescas nos es desconocida, quizá sirvieron como guía para hacer porciones del alimento que se cocinaba en ellas y su contenido, o tal vez tengan que ver con algún elemento de suspensión. Por ahora sólo conocemos un caso comparable en una pieza de Segóbriga.. Es un fragmento de borde y pared de una fuente de TSHB con seis trazos paralelos agrupados sobre el labio (Abascal; Cebrián 2007, 149, fig. 115). Se halló en la plaza del foro y según los citados autores podría indicar un tipo de cómputo (ibidem).

Son destacables el ejemplar con grafito interno $T$ (iti) Val(erii) $T$ (...) con cuádruple nexo TVAL, pues ya hemos visto cómo idénticos tria nomina se repetían en platos hisp. 15/17 (Fig. 11, n $^{\text {os }} 7$ y 8) y un plato de $36 \mathrm{~cm}$ de diámetro la pieza mejor conservada, actualmente expuesta en el Museo Numantino, en la cual la ausencia de huellas de fuego sugiere que no había sido usado aún (Fig. 21).

En cuanto a tipología, predominan los platos de borde entrante, ligeramente engrosado, de pared curva u oblicua, alguno de los cuales alcanzan un tamaño considerable $(36,3 \mathrm{~cm})$ y que son asimilables a la forma Hayes 181, aunque se trate de producciones locales. No obstante, también existe otra variante de tamaño menor $(26,2 \mathrm{~cm})$ con borde en forma de bastoncillo. Platos muy similares al primero de los tipos se han hallado en Pompaelo, coexistiendo con vasos de TSHT de la forma 37 (Mezquíriz 1978, fig. $55 \mathrm{n}^{\circ}$ 18, fig. $110 \mathrm{n}^{\circ}$ 98) y en la necrópolis lusitana de Valdo-

${ }^{5}$ Al igual que hemos mencionado para la TSH, de esta producción común también se recogieron algunas piezas que no se muestran en las láminas. Son un gran plato (de $36 \mathrm{~cm}$ de diámetro en la boca) de pared curva, borde entrante sin labio y fondo plano, una olla globular con el cuello marcado y borde hacia dentro con ranura interna, y el borde entrante ligeramente engrosado de un cuenco. El plato y la olla, (Fig. 21) están expuestos en el Museo Numantino (Soria). ca en ajuares de sepulturas cuya cronología se prolonga hasta mediados del siglo III d. C. (Alarção 1966, 1011). También en el nivel 2 del edificio termal hallado en Turiaso (Beltrán; Paz 2006, 140, Fig. 70) y datado en el tercer cuarto del siglo III.

Entre los recipientes de esta producción culinaria hay también vasos. Se trata de dos piezas de reducidas y prácticamente idénticas dimensiones (de $9,4 \mathrm{~cm}$ de diámetro en la boca y 8 y $9 \mathrm{~cm}$ de altura respectivamente), cuyo perfil es piriforme con la base plana muy estrecha y el borde saliente de sección triangular (Fig. 17, $\mathrm{n}^{\mathrm{o}} 6 \mathrm{y} \mathrm{n}^{\circ} 7$ ). Su factura presenta grandes similitudes con la de algunas ollas del mismo conjunto (por ejemplo, la $n^{\circ} 3$ de la Fig. 17) lo que nos hace pensar que posiblemente provengan del mismo alfar, al igual que los platos. Sin embargo, sus paralelos más cercanos desde el punto de vista formal los encontramos en ejemplares procedentes de las excavaciones de Conímbriga (Alarção et alii 1975, Pl. XVIII, no 372) y de la necrópolis luso-romana de Valdoca (Alarção 1966, 10). También responde a ese perfil el fondo (Fig.18, n $^{\circ} 7$ ) de un recipiente algo mayor, pero de análogas características.

Ya en otro grupo de cerámicas de cocina hay que citar un mortero de borde horizontal con base plana ligeramente resaltada mediante una acanaladura (Fig. 17, no 8 y Fig. 8) que se halló en perfecto estado de conservación. Puede ser una imitación de la forma itálica Dramont D2, en cuya última fase evolutiva se aprecia una tendencia a la horizontalidad en el borde. Los perfiles más semejantes a éste se desarrollan a partir de época de los Antoninos (Aguarod 1991, 140-141). Sin embargo, en su mayoría, las imitaciones estudiadas en Huerña (Domergue; Martín 1977, 76, Fig. $19 n^{\circ} 320$, 56, Fig. $13 n^{\circ}$ 193-195), Turiasso (Aguarod 1985, 30, Fig. 6 n 7), Pompaelo (Mezquíriz 1978, estrato IV) y Arcóbriga (Caballero 1992, 268 $\left.\mathrm{n}^{\circ} 34\right)$ se caracterizan por poseer una acanaladura en la parte interna de la pared, próxima al borde, de la que carece este ejemplar. Aunque el uso de este tipo de mortero se generaliza durante el siglo I d. C., perduran hasta época bajoimperial (Vegas 1973, 32-33).

\section{Formas cerradas}

Las ollas son el tipo de recipiente más numeroso con 10 ejemplares, de los cuales 8 conservaban el perfil completo (Fig. 15, n ${ }^{\text {os }} 4$ y 5 , fig. 18, 1-3 y 5 y fig. $17, \mathrm{n}^{\text {os }} 1$ y 2). Predominan las formas ovoides de base plana cuyos bordes son muy variados: de sec- 

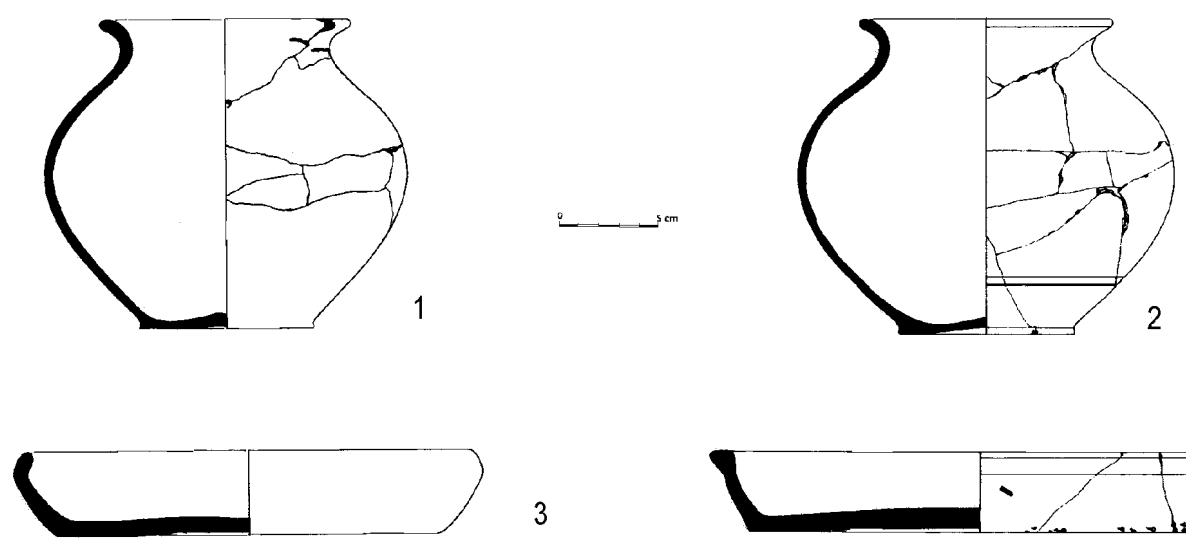

3
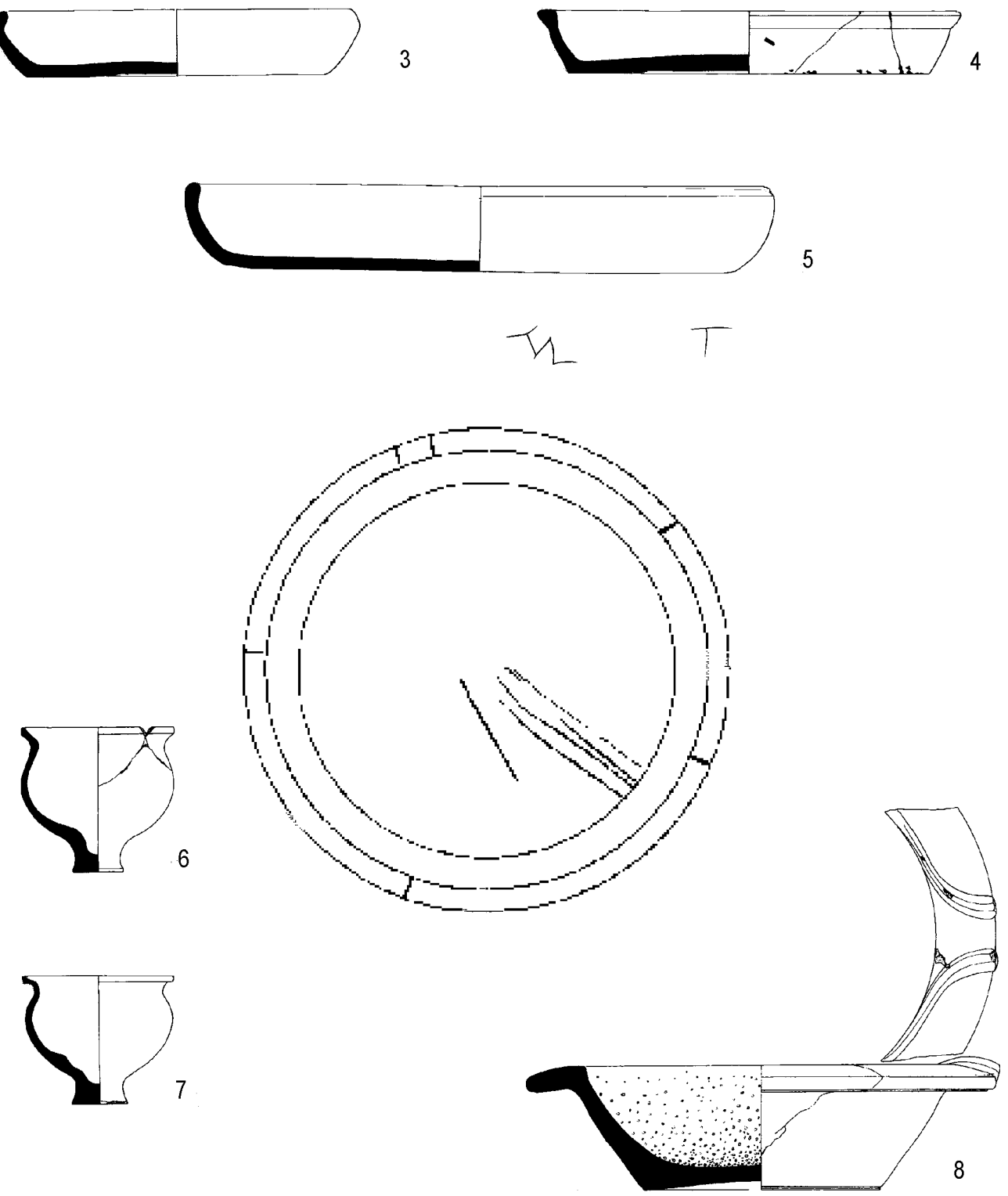

Figura 17. Habitación $n^{\circ} 7$. Nivel de destrucción. Cerámica común. Ver inventario. 
ción triangular, con ranura interna, y engrosado (ya sea ligeramente colgante o bien oblicuo). También está presente la variante de perfil globular con el borde más o menos vuelto. Las dimensiones no son homogéneas ni en el diámetro de la boca (entre 12,2 y $17,4 \mathrm{~cm}$ ) ni en la altura (entre 14,5 y $21,6 \mathrm{~cm}$ ). Las pastas son ocres, marrones, grises o negras, conseguidas mediante cocciones reductoras; también en las piezas se aprecian manchas ahumadas debido a su prolongada exposición al fuego. Se han publicado recipientes de diferentes yacimientos, y entre ellos de la propia Uxama (García Merino 1995), con similares rasgos formales hallados en contextos altoimperiales y bajoimperiales. Sin duda estamos ante modelos muy difundidos geográfica y cronológicamente, que perduran y presentan multitud de variantes locales. De hecho, se encuentran paralelos concretos para algunas piezas tanto en Hispania (en los yacimientos de Huerña (Domergue; Martín 1977, 115, fig. $29 \mathrm{n}^{\circ}$ 578), Conímbriga (Alarção et alii 1975, Pl. XVIII n ${ }^{\circ}$ 356), Poblado de San Esteban (Burillo 1981, 256, fig. $47 \mathrm{n}^{\circ}$ 8), Tiermes (Argente et alii 1984; Casa, de la et alii, 1994, 105, Fig. $50 \mathrm{n}^{\circ} 1221$ y 2415) y en las necrópolis lusitanas de Valdoca y Aljustrel (Alarção 1966, sep. 12 n ${ }^{\circ}$ 10; Alarção 1974), como fuera de ella (Bonnet et alii 2006). Junto con el grupo de las ollas, debemos mencionar la parte inferior del recipiente (Fig. 18, n 6) que apareció sirviendo como tapadera a la vasija de cerámica pintada de tradición indígena $n^{\circ} 1$ de la figura 14 .

Ánforas

Respecto a las ánforas, durante la excavación se recuperó un ejemplar de Dressel 2/4 (Fig. 19, $n^{\text {os }} 1$ y 3), con borde simple redondeado, marcada carena y asas geminadas. Este tipo de ánfora vinaria fue fabricada a imitación de las itálicas en la Tarraconense, de dónde parece proceder esta pieza, como indican las características de la pasta y la carencia de engobe (Comas i Solá 1985, 70-71). Su fabricación se documenta desde época augústea siendo muy abundante en los contextos flavios (Peackok; Williams 1986, 105-106). Pero, aunque tradicionalmente se ha sostenido que su desaparición se producía a inicios del siglo II d. C., en Baetulo y Valentia continúan teniendo una representación abundante durante época adrianea e incluso hasta mediados del s. II d. C. (Comas i Solá 1985, 156; Fernández Izquierdo 1984, 32). De este tipo de envases se ha recuperado también la boca (de $18 \mathrm{~cm}$ de diámetro) y arranque de asas de otro ánfora de salazón (Fig. 19, n 2). Además se recogieron diversos fragmentos correspondientes a distintos recipientes, cuya pasta y engobe sugieren un origen bético y permiten pensar en la presencia de algún ánfora olearia.

\section{Cerámica común tradicional}

De cerámica local es la jarra $n^{\circ} 4$ de la figura 19 . Se trata del borde, cuello y asa geminada con botones aplicados a lo largo del surco central, de una botella de pasta muy fina color arena pálido. No se aprecia ningún motivo pintado que, en su caso, podría haber decorado el tercio superior del cuerpo y los hombros. La forma está en la línea de las botellas de tradición, pero no hay que descartar que sea una imitación de otras producciones aunque la pasta y la decoración aplicada la sitúan mejor dentro de la alfarería tradicional arévaca.

\subsection{VIDRIO}

La mayor parte de las piezas halladas presentan un estado muy fragmentario por lo que su atribución a formas concretas es, en muchos casos, imposible (Fig. 20, no $\mathrm{s}$ 7-12). Son vidrios transparentes o translúcidos, incoloros, de tono algo blanquecino o de color verdoso, que morfológicamente se asocian a recipientes de pequeño tamaño para beber, con bordes engrosados o exvasados. Se ha podido reconocer la forma Isings 45 (Fig. 20, n 8), un cuenco de borde tubular datado desde Augusto hasta la dinastía flavia (Isings 1957, 59), si bien también se halla presente en contextos de los siglos III, IV e, incluso, v (Flos 1987, 69; Alarção et alii 1976, 193-194). En cuanto a las bases, destaca un fondo horizontal separado del cuerpo por un cordón externo (Fig. 20, $\mathrm{n}^{\circ}$ 13), pieza similar a otra hallada en un pavimento de las termas de Conímbriga que se data en el siglo IV (Alarçâo et alii 1976, 186).

\subsection{Objetos de metal y de hueso}

Junto al ajuar cerámico asociado a los servicios de mesa, culinario y de almacenamiento también se recuperaron diferentes utensilios aparte de restos del mobiliario. Concretamente sobre el suelo de la estancia, cerca de la pared occidental de la habitación se hallaron dos objetos metálicos —un cuchillo y un punzón- ambos de hierro con enmangue de hueso (Fig. 20, $\mathrm{n}^{\text {os }} 4$ y 5), que estaban junto a los restos de una pata de cáprido. Otras piezas de hierro de este 

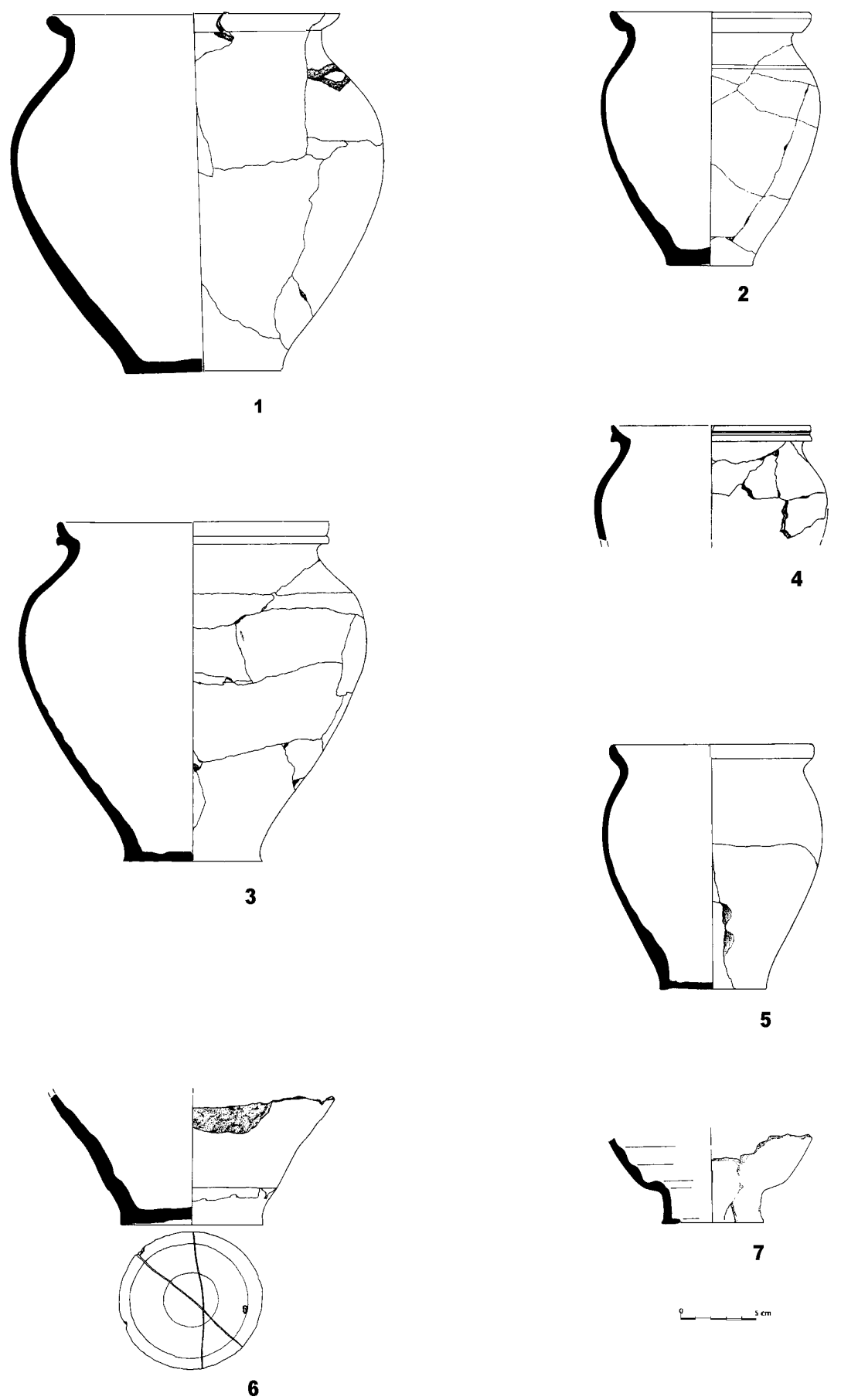

Figura 18. Habitación $n^{\circ} 7$. Nivel de destrucción. Cerámica común. Ver inventario.

contexto son un fragmento de paletón de llave (Fig. $20, \mathrm{n}^{\circ} 2$ ), una hoz que conserva parte de la madera del mango (Fig. 20, $\mathrm{n}^{\circ}$ 1), dos bisagras de una puerta, una aldabilla, numerosos clavos de diferentes ta- maños de muebles y puertas y vigas. A ello se añade un fragmento casi plano de un objeto de plomo. Elementos similares a los aquí descritos son bien conocidos en la bibliografía existente. A modo de 

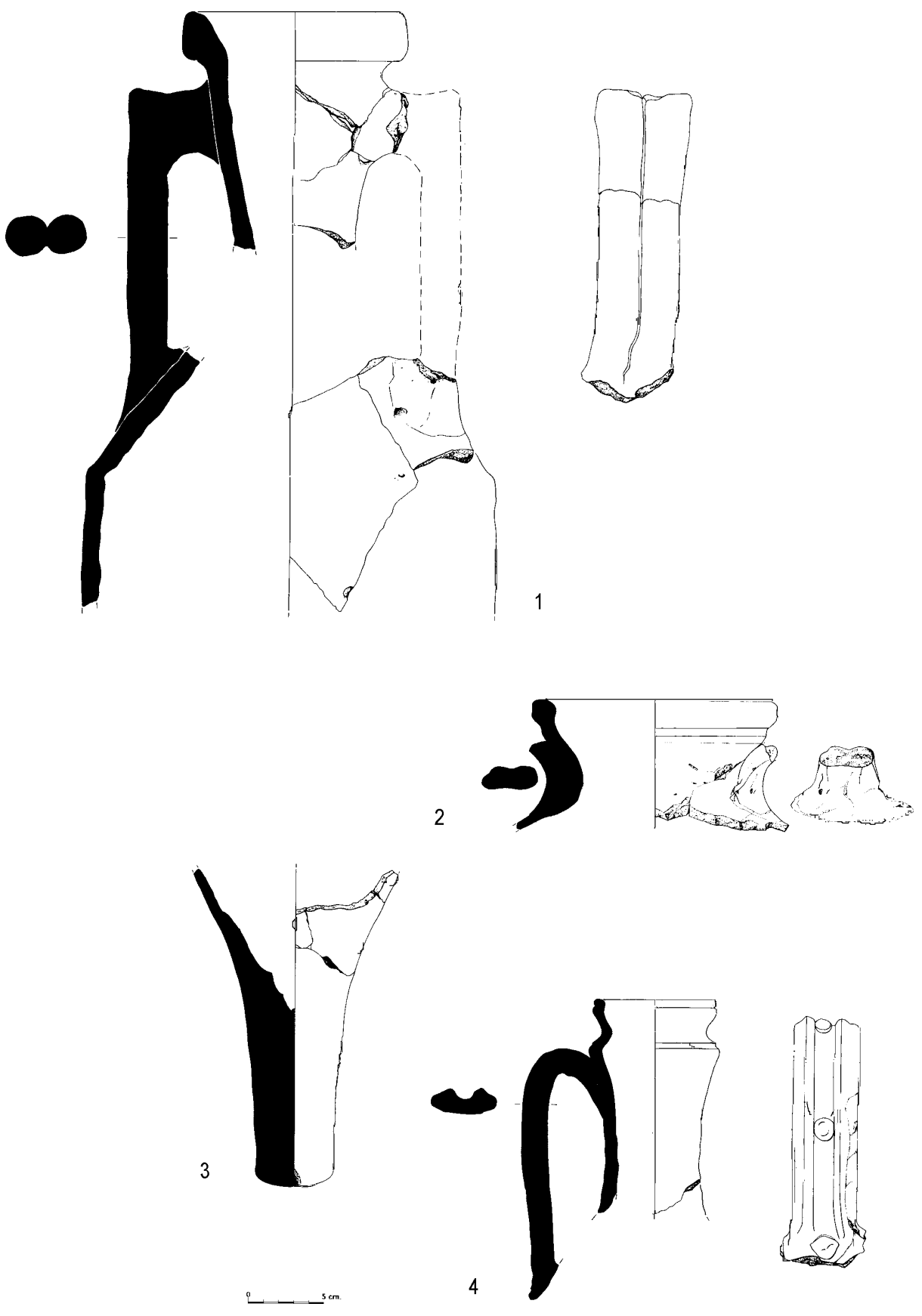

Figura 19. Habitación n ${ }^{\circ}$ 7. Nivel de destrucción. Cerámica común. Ver inventario.

ejemplo valgan los publicados de la propia Uxama (García Merino 1995a, fig. 65, $\mathrm{n}^{\circ}$ 1) y de la cercana Tiermes (Argente et alii 1984).

Por último, cabe mencionar un anillo de bronce con un estrecho chatón decorado con una hoja nervada (Fig. 20, $n^{\text {o } 3) ~ q u e ~ s e ~ e n c o n t r a b a ~ j u n t o ~ a ~ u n a ~}$ tésera monetiforme y dos sestercios, como si hubieran estado dentro de una bolsa o faltriquera. De bronce es también un pequeño instrumento con punzones en ambos extremos.

Completan el ajuar de la estancia cuatro bisagras de hueso (Fig. 20, $n^{\circ}$ 5) de un mueble. 

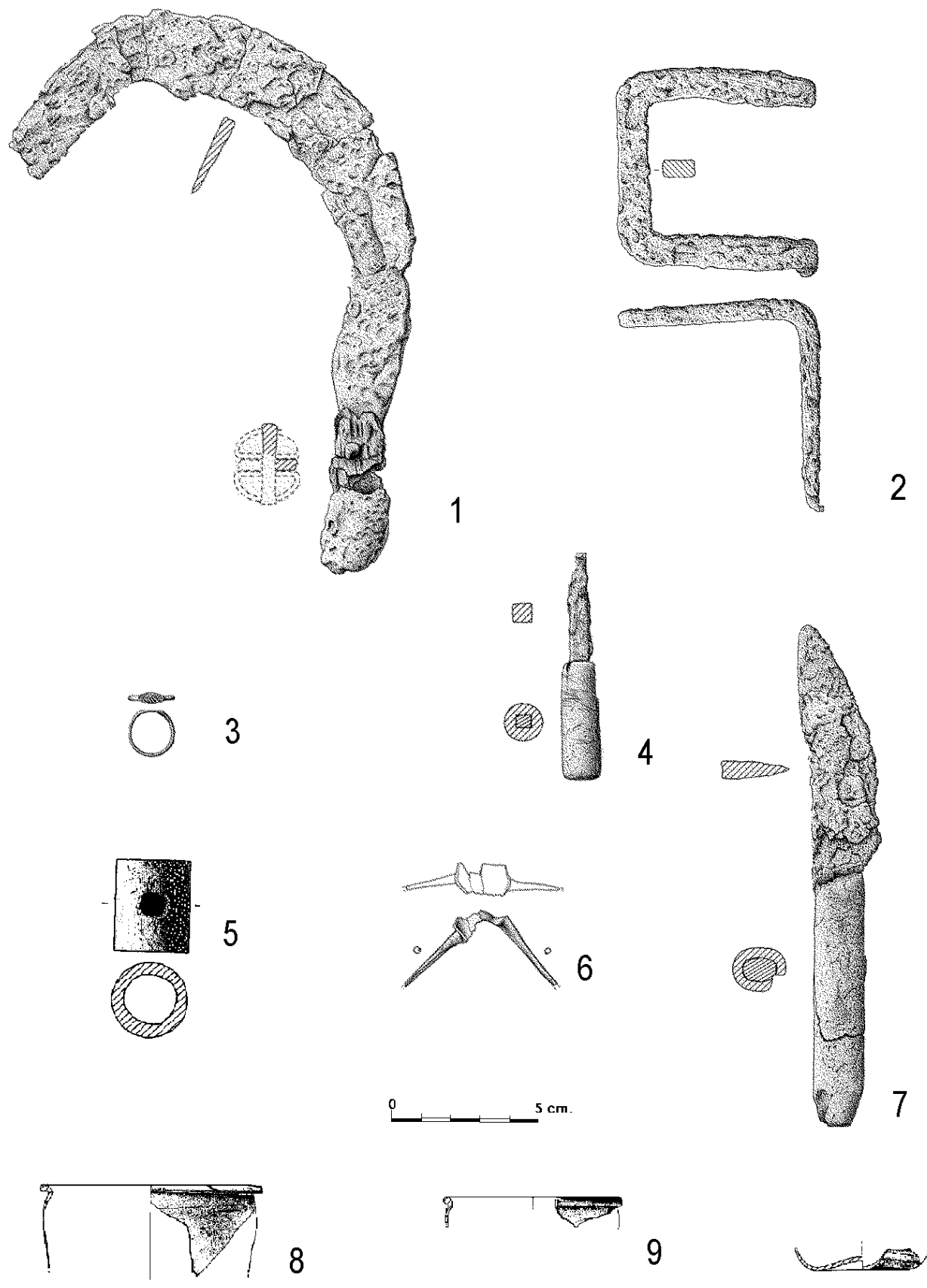

9

10

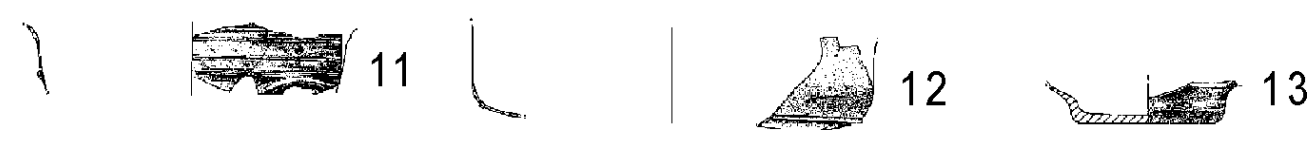

Figura 20. Habitación $\mathrm{n}^{\mathrm{o}} 7$ Nivel de destrucción. Materiales de metal, hueso y vidrio. 


\subsection{TERracota}

En el ángulo sudeste de la habitación se recogieron nueve pesas de telar de diferentes tamaños y pesos. Llevan marcas diferentes, posiblemente relacionadas con su peso. Abundantes restos de madera carbonizada y clavos situados entre ellas revelan la presencia de un pequeño telar vertical doméstico.

\subsection{RESTOS ORGÁNICOS DIVERSOS}

Buena parte de los restos de madera carbonizada, muy abundantes por doquier, se agrupaban en el centro de la habitación marcando unas alineaciones que podrían responder a una estructura mobiliar volcada. Pudo tratarse de una estantería, armario o arca que protegió a buena parte del menaje del aplastamiento por caída de la techumbre (Fig. 7). Hay que señalar que algunos de los fragmentos leñosos estaban teñidos de pigmento azul.

En el ángulo noreste de la estancia entre ceniza y carbón se recogieron huesos de conejo, cordero, y cerdo o jabalí, posiblemente de piezas de carne guisadas o crudas que se conservaban allí. Muy cerca de las monedas y el anillo, en el punto donde el carbón era más abundante, había una pata de cabra o corzo y junto a ella el punzón y el cuchillo lo que parece sugerir la presencia de una pequeña mesa o soporte sobre el que se encontrarían. Todas estas piezas quedaron protegidas por algún elemento orgánico desaparecido, pues no están afectadas por el fuego.

\subsection{Material nUmismático}

En las unidades estratigráficas correspondientes al depósito formado en esta habitación durante en el incendio que destruyó el edificio se han hallado cinco piezas que han sido publicadas dentro del conjunto del numerario de la casa (García Merino 1995b, 19697 y fig. 2, $\mathrm{n}^{\text {os }} 3,22,29,32$ y 39). Son un as de Segóbris, un as de Vespasiano, un sestercio de Trajano, un sestercio de Antonino Pio y una tésera monetiforme con contramarca de cabeza de águila. Se encontraban junto al anillo de bronce mencionado más arriba, tal vez porque se guardaron las monedas y el anillo en una bolsa dentro del armario o en los estantes donde estaba la vajilla. El sestercio de Antonino Pio se encontró debajo de un vaso carenado.

Los bronces son residuales y es muy posible que la tésera resellada se empleara como as cuyo peso tiene. Se trata de numerario de poco valor, nada sor- prendente en una zona de servicio de la casa, aunque si se considera en conjunto el material numismático de toda la vivienda en esa época, se hace patente la pobreza de la masa monetaria en circulación.

\section{PARALELOS}

Para valorar adecuadamente el ajuar de la habitación $n^{\circ} 7$ de la Casa de los plintos de Uxama, no hay que olvidar que es sólo una pequeña parte de la dotación de toda la domus y que procede de una dependencia de servicio, sin embargo creemos que es válido estudiarlo como una muestra representativa de la cultura material de la época. Con el fin de comprender el alcance de su significado respecto a la artesanía y a las condiciones económicas y sociales en las que se enmarcaba, habría que analizarlo en comparación con otros conjuntos, cuantos más mejor, fiablemente coetáneos y de ambiente similar, contrastándolos primero a escala regional, en la Meseta, y luego ampliándolo el alcance a conjuntos más lejanos. Lamentablemente no hay por ahora en la bibliografía disponible conjuntos contemporáneos en la Meseta y apenas fuera de ella y los que hay, en diferentes regiones con sus inevitables particularidades, no son todos de carácter doméstico. A pesar de ello, es interesante la comparación por las analogías y diferencias que pudieran observarse y porque es susceptible de ofrecer una serie de rasgos comunes que contribuyan a definir esa etapa de la segunda mitad de la tercera centuria, tan mal conocida desde el punto de vista material.

En cuanto a conjuntos cerrados de materiales del siglo III, se han publicado otros dos, uno hispano y otro galorromano. Ambos son producto, como el de Uxama, de circunstancias peculiares tras un incendio que destruyó la vivienda (los incendios debían ser muy frecuentes a causa de la fuente de iluminación empleada y de la existencia de mucha madera en la construcción doméstica, tapial o forjados, etc.) y, como ocurrió en la Casa de los plintos, la domus gala tampoco volvió ocuparse.

La casa hispana cartaginense se incendió a mediados del siglo III. Se ha excavado sólo parcialmente. El depósito, situado en torno a un posible hogar contenía sólo 10 vasos. Se supone que la vajilla se apilaba en la zona de la cocina y, según los autores del estudio (Vidal; de Miguel, 1988), era el ajuar mínimo indispensable para una familia media de la época. Se compone de dos cuencos y una fuente de sigillata hispánica, un plato y un plato-escudilla de terra sigillata clara, una jarra, un mortero y una 
vasija de cerámica común, un cuenco de vidrio y una lucerna.

El conjunto doméstico galorromano tiene un mayor paralelismo con el de la ciudad del Duero por el mayor número y la variedad de piezas, aunque parece ser más temprano. Se halló en un sótano de la Casa de los dioses océanos de Vienne, una vivienda grande y de alto nivel económico y social, aspectos que permiten compararla con la de los plintos. Estaba en una cisterna habilitada como sótano en el siglo II (170 d.C.) y abandonada después de 192 (Leblanc; Desbat 1993). El conjunto de materiales propio de una despensa, en el que se han reconocido 25 formas diferentes, se compone de unas 70 piezas, muy pocas completas (ibidem). La mayoría es de producción local, aunque también hay importaciones. Muchas de las piezas son de finalidad culinaria y almacenamiento, pero también hay vajilla de mesa. Se trata de un conjunto temprano dentro del siglo III que no acusa prácticamente cambios respecto al siglo anterior: ese hecho es lo que lo asemeja al conjunto uxamense.

Finalmente conviene también considerar el conjunto de la habitación $\mathrm{n}^{\mathrm{o}} 7$ de la Casa de los plintos en comparación con otros materiales de niveles datados en el siglo III, procedentes de otras dos ciudades hispanas, Iaca y Turiaso, aunque no de ambiente doméstico, y otro doméstico pero rural. En excavaciones realizadas en 1985 en Jaca (Ona; Paz; Pérez; De Sus 1987) se documentó un posible macellum y en él un nivel de la misma centuria que presentaba, además de la consabida cerámica común de cocina, las mismas tres formas de sigillata hispánica lisa que hemos visto en la Casa de los plintos: hisp. 8, 15/17 y 27 de Tricio. Había, en cambio, una forma decorada con sencillos motivos vegetales, la hisp. 37, y sigillata clara que no están presentes en la habitación 7 de la casa uxamense.

Las monedas halladas en este nivel —bronces residuales de Vespasiano, Domiciano y Faustinaabundan en los rasgos que para la circulación monetaria de esa época se han visto en Clunia, en Sagunto y en la propia Uxama, como hemos señalado más arriba.

En Turiaso, en un edificio termal (Beltrán; Paz 2004), se ha registrado también un nivel de esa centuria con unas características comunes al uxamense en cuanto que se trata de un conjunto de piezas con predominio de formas lisas en sigillata hispánica donde abundan los cuencos 8 y los platos 15/17 que consideramos como un servicio de mesa. También se ha hallado un objeto residual muy preciado, un arca de bronce decorada con bellos relieves de tema floral y representaciones mitológicas, bastante más an- tigua que la cerámica y que, como el lampadario de la Casa de los plintos, se había conservado más de un siglo (ibidem 103-180).

Finalmente, fuera del ambiente urbano hay que mencionar por similitud cronológica materiales cerámicos de cocina y en menor medida de mesa, y un depósito monetario de la pars rustica de una villa del nordeste hispano, la de Vilauba, destruida por el fuego en la segunda mitad del siglo III (Roure; Tremoleda; Castanyer 1989, 268-281). Los materiales cerámicos son de uso común: tanto cerámicas locales groseras de cocina como importadas. Son ollas y jarras para conservar alimentos, además de cerámicas comunes oscuras por oxidación para comer y para contener líquidos y sólidos, y ánforas.

Finalmente hay que señalar que los rasgos que presenta la sigillata hispánica de la Casa de los plintos en la segunda mitad del siglo III, época de su destrucción, se corresponden con los de la terra sigillata hispánica avanzada de Clunia (Tuset; Buxeda 1995).

Las monedas, un conjunto caracterizado por la presencia de gran bronce, abarcan un periodo de 100 años, de Antonino Pio a Galieno. Suponen los autores que la poca variedad monetal se debe a la situación de la villa en el campo.

En cuanto a la circulación monetaria a escala doméstica de la Casa de los Plintos tiene un paralelo en el conjunto numismático (Llorens; Ripollés 1995, 217- 228) procedente de una casa excavada en Sagunto (López; Chiner 1994, 229-237). En él domina igualmente el sestercio y hay una alta proporción de monedas del siglo II circulando todavía a mediados del siglo III.

De lo visto se desprende que la mayor parte de los rasgos que caracterizan a los conjuntos cerámicos y numismáticos de los yacimientos mencionados son comunes al material documentado en la habitación $\mathrm{n}^{\mathrm{o}} 7$ de la domus uxamense.

\section{CONSIDERACIONES FINALES}

\section{El AJUAR DE LA HABITACIÓN 7}

En el lote de material cerámico, el más abundante, se distinguen: a) vajilla de mesa (servicios de plato y cuenco en sigillata y cuencos carenados, vasos bitroncocónicos con dos asas de cerámica pintada, vasitos de cerámica oscura común y jarras, una de sigillata hispánica y otra de sigillata brillante. b) Recipientes para guardar alimentos sólidos y líquidos (algún dolio, una orza y dos grandes jarras), contenedores de vino y salsas (ánforas) y c) recipien- 
tes para cocinar (ollas medianas y pequeñas, platos con revestimiento antiadherente para patellae o similares y mortero). Completaban el ajuar una lámina de plomo, quizá de algún recipiente o utensilio, un cuchillo, un punzón y parte de una llave de hierro, el contenido de una faltriquera (el anillo, las monedas y la tésera), madera y elementos de algún mueble y restos óseos de diversos animales que fueron parte integrante de la comida conservada, algunos domésticos (cordero), y otros fruto de la caza (conejo, jabalí y venado)

Había, además, un pequeño telar manifiesto por las pesas y los restos de madera quemada hallados en el ángulo sureste de la estancia y que, dadas las reducidas dimensiones de la habitación, parece lógico pensar que no estaría en uso.

Llama la atención la ausencia de lucernas u otro tipo de lámpara en la habitación, si bien en el resto de la casa son también contados los fragmentos de ese material cerámico, sustituido posiblemente por velas. Por ello destaca la presencia en el atrio del lampadario de bronce, que en ese contexto se puede considerar con mayor razón un elemento suntuario.

\section{El menaje}

La vajilla de mesa la componen los tres servicios de plato 15/17 y cuenco 8 de sigillata hispánica, cuencos más pequeños hisp. 8 , vasos decorados con pintura carenados y bitroncocónicos con asas, jarrita de TSH, tan pequeña que tal vez se usase para servir o añadir aceite o salsas en la comida, jarra lisa de tradición local, jarra de sigillata brillante, platos de cerámica común oscura para servir comida y algunos vasos de vidrio. La estrecha base de los vasitos de cerámica común oscura (Fig. 17, no 6 y n 7 y $\left.18, n^{\circ} 7\right)$ los dota de una precaria estabilidad en el caso de utilizarse para beber, por ello parece más probable que sirviesen para contener sólidos que se emplearan en pequeña cantidad, como sal o, mejor, algo ligero como son los aliños de hierbas. A propósito de las hierbas, la casa dispone de un amplio espacio al aire libre, jardín-viridario, donde seguramente habría entre otras especies decorativas, plantas aromáticas y utilizables en la cocina, como romero, salvia, albahaca, melisa, perejil, perifollo, cebollino, etc. En ese contexto se podría explicar quizá la presencia de la hoz.

En cuanto al menaje de cocina y almacenamiento, en espera de realizar análisis de cromatografía de gases a las piezas, se puede conjeturar que la mayor parte de las formas cerradas serían para guardar ali- mentos y, en menor medida, para cocinar (ollas): no hay cazuelas, pero para guisar servirían por ejemplo algunas ollas y los platos con engobe antiadherente $\mathrm{y}$, desde luego, el mortero para las salsas, majados y aliños, básicos en la cocina romana. Hay también recipientes para guardar líquidos como agua, (Fig. 15, $\mathrm{n}^{\mathrm{o}} 2$ y 3), vino, salsas y aceite (Fig. 19) y otros para sólidos (como legumbres, frutos secos, miel, leche, queso o mantequilla, conservas, chacinería envuelta en manteca (en ollas, orzas y dolios, posiblemente con tapas de madera o tela encerada, dada la ausencia de tapaderas de cerámica), quizá cecina (piénsese en el hueso de una extremidad de cabra o corzo hallado con el cuchillo y el punzón). También pudo haber alimentos frescos, y otros tal vez ya cocinados. La concha de vieira pudo utilizarse como platito o estar allí por otra razón, pues una, aislada, no resulta suficiente para considerarla ingrediente de la comida en ese contexto del interior de la Meseta.

Respecto a los cuencos pequeños, tanto de TSH como de СРт cabe suponer su empleo para beber, así como el de los frágiles de vidrio, escasos, y que han quedado muy fragmentados. No se han documentado cucharas de metal. Seguramente no todos los elementos de uso en la mesa se encontraban en esta pequeña estancia. A lo que se halló habría que pensar que tal vez acompañaron recipientes y utensilios de madera que, debido a su naturaleza, no se han conservado.

\section{Funcionalidad de la vajilla de mesa}

En sigillata ya hemos visto que hay platos y cuencos de tres tamaños diferentes. En cerámica pintada no encontramos platos ni fuentes, sino formas abiertas, cuencos o vasos para beber y contener líquidos o comidas preparadas en forma fluida, tipo gachas, o legumbres y verduras con caldo, como los cuencos más grandes de TSH. De ello no podemos concluir directamente que respondan a cambios en la alimentación respecto a la etapa anterior ni extraer información de carácter económico. La dificultad para hacerlo ha quedado patente en un minucioso estudio sobre Britania basado en el registro arqueológico de un considerable número de yacimientos (Cool 2006, 242). No cabe duda de que la población local había ampliado con la influencia romana su horizonte gastronómico, como prueban los morteros —objeto imprescindible en la cocina romana y siempre presente en el menaje de las casas de esa época y anteriores- que se han exhumado en diferentes yacimientos y zonas del Imperio. Sin embargo, la escasez de 


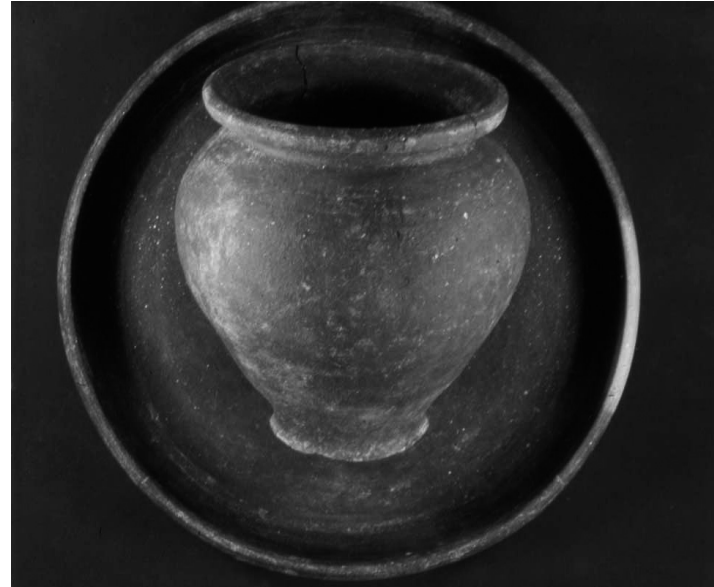

Figura 21. Habitación $n^{\circ}$ 7. Nivel de destrucción. Plato y olla de cerámica común.

excavaciones en ambiente doméstico y la falta de análisis de restos orgánicos documentados en ellas, nos priva más aún en Hispania de la información necesaria para conocer los elementos que conformarían la dieta y sus variantes regionales.

\section{Función de la habitación 7}

Aunque averiguar la función de los espacios de una casa es uno de los objetivos más difíciles de alcanzar, incluso en Pômpeya, tan rica en información (Allison 2004, 11), en el caso que nos ocupa la cosa parece clara. La habitación $\mathrm{n}^{\circ} 7$ orientada al norte y con gruesos muros tuvo excelentes condiciones para haber sido una cella penaria. No tenía comunicación directa con la cocina (Fig. 3,8) pero sí con un espacio con posible función de comedor, la sala $n^{\circ} 5$ (Fig. $3,5)$. En la dependencia 7 no sólo se guardaba vajilla, sino también alimentos como parece avalar su contenido. La decoración pictórica parece poco congruente con tal uso de almacenamiento, pero hay que tener en cuenta que sus paredes eran en realidad elementos residuales de la Fase I de la casa, cuando el cometido de ese ámbito debía de ser diferente.

\section{Aspectos sociales}

Los grafitos sobre el menaje nos trasmiten el nombre de sus usuarios, en principio sus dueños, aunque también podría tratarse de siervos como sucede en otras ocasiones (Sánchez-Lafuente 1991, 45; idem 1997, 571-72). Sin embargo, el uso de duo nomina y la repetición de una misma denominación sobre cuencos 8 y platos $15 / 17$ de TSH y sobre tres platos/ fuentes de $\mathrm{CC}^{6}$ en la que aparece la gens Valeria, citada en varios epígrafes de Uxama, frecuente también en Clunia y otras ciudades de la Meseta, da pie a conjeturar que $T$. Valerius $T(\ldots \ldots)$ podría ser el dominus, o, al menos, que los Valerii habitaban la Casa de los plintos.

Los repetición de los mismos nombres sobre plato y cuenco de TSH refuerzan la deducción de que ambos forman un servicio de mesa. El mismo grafito de propiedad aparece en un plato o fuente de CC.

Para algunos autores que han estudiado estos aspectos en Britania la drástica disminución del número de jarras y el incremento de formas (platos, copas, cuencos) relacionables con un servicio de mesa individual son rasgos que caracterizan la intensa romanización de un ajuar (Millett 1997, 37-39; Evans 1993, 100). En ambiente urbano y ya en una fase tan avanzada como la segunda mitad del siglo III, eso es lo esperable en Uxama y por ello carece de tal significado. Por otra parte, no sabemos si los servicios individuales en la vajilla de mesa existían con anterioridad en esta zona o en otras de Hispania porque no se ha estudiado ese aspecto de la cerámica. En el caso de que fuesen propios de la época en que se utilizaban los que se presentan en este trabajo, es más plausible que la clave de su significado sea social.

\section{CONCLUSIONES}

En cuanto a la cerámica del conjunto en estudio, se puede afirmar que los rasgos que presenta la TSH, por encima de su probable origen local, son encuadrables en la generalidad de los paralelos ya comentados y coinciden, como era previsible, con los descritos de la TSHA de la cercana Clunia. Coinciden en la pobreza tipológica que, salvo algunos platos, da protagonismo, casi exclusividad, al cuenco hisp. 8 entre los vasos, aunque aún hay un ejemplar de forma 27, y se asemejan igualmente, como las producciones del Duero a la que las uxamenses pertenecen, en la total ausencia de formas decoradas a molde (Tuset; Buxeda 1995, 361-362). La forma 37 decorada con un solo friso de rosetas o de sencillos motivos que en niveles de comienzos del siglo III se ha documentado en otros puntos de la casa, aquí no está

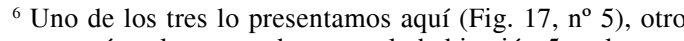
se encontró en la puerta de paso a la habitación 5 y el tercero en el patio.
} 


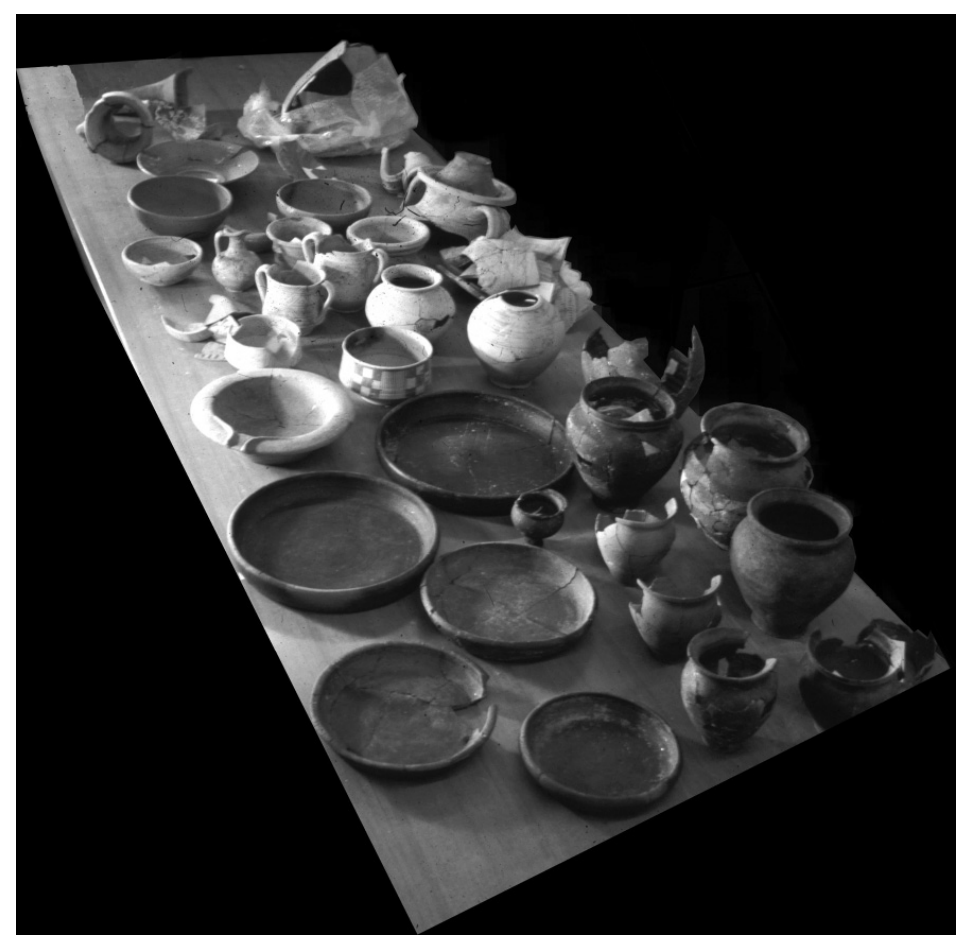

Figura 22. Habitación $\mathrm{n}^{\circ}$ 7. Nivel de destrucción. Vista general de la mayor parte de la cerámica: terra sigillata hispánica, cerámica pintada de tradición y cerámica común.

en el momento del incendio. La falta de formas cerradas que en Clunia muestran las cerámicas del Duero, se palía en el depósito que estudiamos por la jarrita para la que un paralelo en Álava, no permite, a falta de análisis físico-químicos de la pasta, asegurar que proceda del complejo alfarero tritiense. Por sus rasgos, pues, podríamos considerar la sigillata hispánica de este conjunto de Uxama como terra sigillata hispánica avanzada.

La CPT muestra una sólida presencia en el ajuar. En ella conviven formas evolucionadas junto a algún perfil arcaizante, como la orza, y formas singulares que parecen imitaciones de las cerámicas comunes, caso de la jarra (Fig. 14,1) y de la ollita (Fig. 22).

En cuanto a la TSHB, es destacable la jarra hallada en el incendio porque demuestra que esta producción cerámica llega, al menos, hasta muy entrado el siglo III.

Cabe, hasta confirmarlo con análisis de fluorescencia, etc., que permitan su caracterización arqueométrica, que la sigillata mayoritariamente y, sobre todo, la cerámica pintada procedan de alfares locales, aspecto que está resultando ser un rasgo común a los conjuntos del siglo III del interior hispano. Esos talleres serían diferentes de los conoci- dos por ahora en $\mathrm{Uxama}^{7}$ que no parecen haber trabajado después del siglo II.

La presencia, aunque sea escasa, de ánforas en esta despensa, que seguramente no era la única de la casa, aparte de probar que se continuaba consumiendo salsas, aceite y vino, también supone una tímida actividad importadora.

El conjunto de piezas que se ha documentado en este espacio no constituía el total del menaje de la casa. De la reducida superficie de la habitación 7 y de la cuantía de su contenido no se debe extraer conclusiones acerca del grado de la pobreza mueble de la vivienda en su conjunto. Hay que tener en cuenta que en otras habitaciones, por ejemplo cerca de los posibles triclinios $\mathrm{n}^{\circ} \mathrm{s} 6$ y 21 de la fig. 3, debió existir más vajilla y objetos relacionados con la mesa, la comida y el almacenamiento. A ello apunta el abundante material recogido en diversos espacios de la

\footnotetext{
${ }^{7}$ Se conocen dos talleres cerámicos de Uxama, uno en el área suburbana, bajo la Catedral de Osma en Burgo de Osma, y otro en Gormaz. Producían terra sigillata, cerámica pintada y cerámica común. Los análisis efectuados a la pasta de las piezas recogidas en excavaciones recientes han mostrado el mismo tipo de arcillas para los dos centros productores (Romero et alii 2008). La cronología del material no parece sobrepasar el siglo II.
} 
amplia superficie de la casa durante las excavaciones. La planta de la vivienda es extensa y desconocemos el número de personas que la habitaban en su etapa final, pudo ser tanto una sola familia, según el concepto latino (núcleo unifamiliar simple del dominus y además sus siervos), como una comunidad más amplia, por ejemplo, dos grupos colaterales de la misma familia y los siervos.

En cualquier caso, el conjunto de objetos que damos a conocer es interesante por resultar una muestra significativa de la asociación de materiales (Figs. 9 y 22) en uso en la vida de una domus de un nivel económico relativamente alto para la época de crisis económica que se estaba viviendo. Esa crisis cabe deducirla aquí de la escasez de importaciones y de la parquedad del numerario disponible. La Casa de los plintos era una vivienda de gente acomodada a juzgar por su extensión y la dotación de jardín, cocina con chimenea, cisterna y decoración pictórica. En ello abundan además algunos objetos relativamente suntuarios que excepcionalmente se han conservado, como el lampadario o el brasero, y también la presencia de ánforas importadas. Pero, a la vez, dado que eso indica que era una casa privilegiada, la mediocre calidad de la parte analizada de su vajilla, la combinación de producciones probablemente locales, la perduración y simplificación de formas, tipos y modelos de la cerámica de los siglos anteriores refuerzan esa impresión de prolongación del pasado, casi de continuidad en precario. Podría decirse que produce la sensación de agotamiento de la capacidad creativa, de escasas relaciones comerciales con el exterior y de crisis, es decir, de preludio de cambio.

Ciertamente los rasgos que definen los materiales de la Casa de los plintos de Uxama en su última fase, documentados en la habitación $n^{\circ} 7$ y que hemos analizado aquí, dan pie para hablar de conservadurismo en la arquitectura y en la decoración pictórica e igualmente de pobreza monetal. Ese ajuar trasluce un panorama de escasez creativa, de localismo y continuidad en las producciones cerámicas y de reducción de la vajilla de mesa a poco más que vasos carenados y cuencos hisp. 8. A la vez hay rasgos que configuran el siglo III avanzado, al menos en esta zona del Duero, como una fase de transición en la evolución de la cerámica. Hay terra sigillata hispánica, siempre lisa, donde predomina el evolucionado cuenco hisp. 8 , y donde ya se prefiguran en la hisp. 27 y en la 15/17 perfiles que en la sigillata hispánica tardía tendrán una larga vida, pero coexistiendo con formas decoradas en un contexto mucho más rico y variado. Asimismo, en la cerámi- ca pintada tradicional aparecen tres piezas: una jarra y dos vasos bitroncocónicos, formas Abascal 22 y 23 respectivamente, que poblarán la siguiente centuria.

\section{INVENTARIO DE LAS PIEZAS}

\section{FIGURA 11}

$\mathrm{n}^{\mathrm{o}}$ 1: TSH. Forma 8 de gran tamaño. Labio almendrado y acanaladura en la parte superior de la pared. Pie muy bajo con moldura hispánica. Grafito EPE EPE, de difícil interpretación, sobre la pared externa. Pasta anaranjada y barniz consistente de similar tono. Medidas: diámetro de la boca: 23,6 $\mathrm{cm}$, diámetro de la base: $7,3 \mathrm{~cm}$, altura: $9,5 \mathrm{~cm}$.

$\mathrm{n}^{\circ}$ 2: TSH. Forma 8. Borde reentrante sin labio, de sección redondeada. Pie bajo con umbo y moldura hispánica. Grafito en la pared externa: Val(eriae?) $I a(. . . .$.$) con triple nexo$ VAL. Pasta rosada, barniz naranja mate poco cubriente. Medidas: diámetro de la boca: $22 \mathrm{~cm}$, diámetro de la base: $7 \mathrm{~cm}$, altura: $9,4 \mathrm{~cm}$.

$\mathrm{n}^{\circ}$ 3: TsH. Forma 8. Fragmento de pie bajo. Pasta anaranjada y barniz de similar tono. Medidas: diámetro de la base: $6,7 \mathrm{~cm}$.

$\mathrm{n}^{\circ}$ 4: TSH. Forma. 8. Borde engrosado, sin labio. Tiene dos acanaladuras en la zona basal. Pie destacado y fondo bastante alto. Grafito en aspa en el fondo externo. Pasta anaranjada, barniz naranja mate poco cubriente. Medidas: diámetro de la boca: $17 \mathrm{~cm}$, diámetro de la base: $6,5 \mathrm{~cm}$, altura: $6,8 \mathrm{~cm}$.

$\mathrm{n}^{\mathrm{o}}$ 5: TSH. Forma 8. Borde reentrante de sección apuntada. Pie destacado y fondo con pequeño baquetón. Grafito S LVP en la pared externa. Pasta y barniz anaranjados. Medidas: diámetro de la boca $10 \mathrm{~cm}$, diámetro de la base: 4,6, altura: $6,8 \mathrm{~cm}$.

$\mathrm{n}^{\mathrm{o}}$ 6: TSH. Forma 15/17. Pared casi oblicua, dividida por acanaladura próxima a la base. Baquetón más alargado y plano. Dos grafitos, _I/R?M y TM, sobre la pared externa. Pasta y barniz anaranjados. Medidas: diámetro de la boca: $28 \mathrm{~cm}$, diámetro de la base: $8,2 \mathrm{~cm}$, altura: $6,4 \mathrm{~cm}$.

$\mathrm{n}^{\circ}$ 7: TSH. Forma 15/17. Pared abierta y base plana con pie bajo con moldura hispánica. Baquetón señalado. Sobre la pared interna grafito TVAL con cuádruple nexo. Pasta y barniz anaranjados. Medidas: diámetro de la boca: $28,2 \mathrm{~cm}$, diámetro de la base: $8,6 \mathrm{~cm}$, altura: $7,5 \mathrm{~cm}$.

$\mathrm{n}^{\mathrm{o}}$ 8: тsH. Forma 15/17. Pared acampanada, con acanaladura en la parte inferior. Baquetón muy destacado. Presenta dos grafitos, uno, TVAL con cuádruple nexo, en el interior y otro, S AE T, con nexo AE, en la zona basal de la pared externa. Pasta naranja, barniz naranja claro prácticamente mate. Medidas: diámetro de la boca: $29,2 \mathrm{~cm}$, diámetro de la base: $8,6 \mathrm{~cm}$, altura: $7,7 \mathrm{~cm}$.

$\mathrm{n}^{\circ}$ 9: TSH. Forma 27. Borde desarrollado y un pie de sección triangular y moldura hispánica que al interior ofrecen círculos incisos. Pasta y barniz muy claros. Medidas: diámetro de la boca: $17,3 \mathrm{~cm}$, diámetro de la base: $6 \mathrm{~cm}$, altura: $5,9 \mathrm{~cm}$.

$\mathrm{n}^{\mathrm{o}}$ 10: TSH. Vasito de perfil troncocónico invertido con carena en la parte inferior del cuerpo. Base baja con moldura hispánica. Barniz anaranjado. Medidas: diámetro de la boca: $13,2 \mathrm{~cm}$, diámetro de la base: $4,8 \mathrm{~cm}$, altura: $6,5 \mathrm{~cm}$.

$\mathrm{n}^{\circ}$ 11: тsн. Fragmento de un vasito de perfil troncocónico invertido con carena en la parte inferior del cuerpo. Barniz anaranjado. Medidas: diámetro de la boca: $9 \mathrm{~cm}$, altura: 14,2 $\mathrm{cm}$.

$\mathrm{n}^{\circ}$ 12: Tsh. Jarra de boca trilobulada, cuello cónico recorrido por acanaladura, cuerpo panzudo y pie destacado y mol- 
durado. Asa de acanaladura central. Barniz rojizo mate, bastante saltado. Medidas: diámetro de la boca: $5,5 \mathrm{~cm}$, diámetro de la base: $5 \mathrm{~cm}$, altura: $14 \mathrm{~cm}$.

\section{FigURA 13}

$\mathrm{n}^{\circ}$ 1: СРт. Vaso carenado Abascal 3a evolucionado con labio almendrado. Pasta ocre rosada con engobe blanquecino al exterior decorado con friso cuyas metopas se rellenan con columnas de puntos y secuencia de trazos oblicuos bajo el labio. Medidas: diámetro de la boca: $20,5 \mathrm{~cm}$; diámetro de la base: $11,5 \mathrm{~cm}$, altura: $9,5 \mathrm{~cm}$.

$\mathrm{n}^{\circ}$ 2: СРT. Fragmento de la parte superior del cuerpo y borde de un vaso carenado Abascal 3a evolucionado con labio almendrado, pasta y características decorativas similares al anterior. Medidas: diámetro de la boca: $20 \mathrm{~cm}$.

$\mathrm{n}^{\circ}$ 3: СРT. Vaso carenado Abascal 3a evolucionado. Labio almendrado. Un surco recorre la parte inferior del cuerpo entre la carena y el pie. Pasta ocre rosada con engobe blanco al exterior. Decoración semejante a los anteriores, pero con mayor número de barras en los triglifos torpemente trazados, lo que reduce el espacio de las metopas. Medidas: diámetro de la boca: $18,5 \mathrm{~cm}$, diámetro de la base: $12 \mathrm{~cm}$, altura: $8,5 \mathrm{~cm}$.

$\mathrm{n}^{\circ}$ 4. СРт: Vaso carenado Abascal 3a evolucionado, casi completo, de tamaño mediano. Pasta y color semejante a los anteriores. Las metopas se rellenan con columnas de pequeños trazos horizontales. Diámetro de la boca: $13 \mathrm{~cm}$, diámetro de la base: $5,6 \mathrm{~cm}$, altura: $6,8 \mathrm{~cm}$.

$\mathrm{n}^{\circ}$ 5: СРт. Vaso carenado Abascal 3a evolucionado, casi completo y de tamaño pequeño. Pasta y color semejante a los anteriores. Decorado con trazo grueso con friso de triglifos muy simples y metopas con una sola columna de trazos oblicuos. Medidas: diámetro de la boca: $10,2 \mathrm{~cm}$, diámetro base: $6,8 \mathrm{~cm}$, altura: $5 \mathrm{~cm}$.

$\mathrm{n}^{\circ}$ 6: СPT. Vaso completo Abascal 23. La pasta es ocre claro con desgrasante micáceo y gránulos de caliza blanca. Lleva engobe blanco al exterior. El vaso se pintó antes de pegar las asas y luego se rehicieron las líneas interrumpidas. La decoración, realizada en pintura negra, muestra un friso entre dos franjas de tres líneas más o menos paralelas, enmarcado arriba y abajo por tres filetes de irregular grosor. En el interior hay una secuencia de rombos delimitados por cuádruple línea. Dos pequeños círculos en columna ocupan el espacio tanto dentro de los rombos como entre ellos. Una raya horizontal recorre el vaso cruzando por el centro el motivo geométrico. Las asas, de $2 \mathrm{~cm}$ de anchura, tienen una acanaladura que las divide en dos partes desiguales y están cubiertas de haces de rayas transversales. Medidas: diámetro de la boca: $11,7 \mathrm{~cm}$, diámetro de la base: $7,5 \mathrm{~cm}$; altura: $13 \mathrm{~cm}$.

$\mathrm{n}^{\circ}$ 7: CPT. Vaso completo Abascal 23 de pasta, color y factura semejantes a las del $\mathrm{n}^{\circ} 6$. Está decorado con trazos irregulares y poco cuidados en pintura negra. Un friso de $6 \mathrm{~cm}$ de altura, entre dos franjas paralelas de cuatro líneas bajo el borde y sobre la carena, está dividido en dos sectores que se extienden entre las asas, dejando en la zona coincidente con éstas un espacio vacío delimitado por delgadas líneas verticales. Triglifos oblicuos jalonan espacios ocupados alternativamente por vermiformes y puntas de flecha. Asas de $2,5 \mathrm{~cm}$ anchura. Medidas: diámetro de la boca: $13 \mathrm{~cm}$, diámetro de la base: $8,3 \mathrm{~cm}$, altura: $15,5 \mathrm{~cm}$.

$\mathrm{n}^{\circ}$ 8: CPT. Vaso carenado forma Abascal $3 \mathrm{~b}$ completo y en perfecto estado de conservación. Pasta ocre rosado con desgrasante de mica e intrusiones de caliza; muestra algunos poros al interior por haber perdido gránulos de desgrasante. Engobe blanco al exterior. Hay dos pequeñas estrías de $1 \mathrm{~cm}$ sobre la carena. Pintado en negro claro con un friso de proporciones irregulares con motivo de damero de 9 cuadros, alternando los negros con los del color pálido del fondo.
Medidas: diámetro de la boca: $16,8 \mathrm{~cm}$, diámetro de la base: $9,5 \mathrm{~cm}$, altura: $10,3 \mathrm{~cm}$.

\section{FIGURA 14}

$\mathrm{n}^{\circ}$ 1: СРт. Gran jarra de almacenamiento. Le falta el fondo. Pasta y factura similares a los vasos anteriores. Decoración limitada al cuello, asas y tercio superior del cuerpo. Cubre los hombros un friso con grandes metopas de trazos algo torcidos y desigual anchura rellenas de franjas paralelas oblicuas de pequeños segmentos. Por debajo, una banda de roleos esquemáticos sobre cinco líneas finas horizontales de las que penden arquillos entrecruzados en posición invertida. Las asas, de $5,5 \mathrm{~cm}$ de anchura, divididas en dos partes por un surco longitudinal, rematan en la base en tres depresiones digitales y están decoradas con trazos oblicuos en espiga. Medidas: diámetro de la boca: $23,5 \mathrm{~cm}$, altura estimable $55 / 60 \mathrm{~cm}$.

$\mathrm{n}^{\circ} 2$ : СРт. Orza o tinajilla globular completa y de forma arcaizante. Pasta color ocre claro con gránulos calizos y engobe blanco. La decoración, restringida al tercio superior es muy simple: cuatro haces de líneas horizontales de diferente de grosor, dos de triple trazo, por encima otro más fino de dos líneas unidas a trechos y, finalmente ya bajo la boca, cuatro listas paralelas de grosor creciente hacia arriba. Medidas: diámetro en la boca: $9 \mathrm{~cm}$; diámetro de la base: $8,8 \mathrm{~cm}$, altura: $18,8 \mathrm{~cm}$.

$\mathrm{n}^{\mathrm{o}}$ 3: СРт. Cuello y boca de una jarra u olpe Abascal 22 de pasta y color similar a los $n^{\circ}$ anteriores, pero de factura más tosca y mayor número de gránulos calizos. El cuello está recorrido por seis gruesas líneas horizontales pintadas en color negro. Medidas: diámetro de la boca: $14 \mathrm{~cm}$.

\section{FigURA 15}

$\mathrm{n}^{\circ}$ 1: CPT. Dolio completo pasta ocre similar al anterior pero más tosca. Decorado en la zona de los hombros con un friso de triglifos y metopas vacías, debajo otra franja lisa y, pendiendo de ella, cinco haces de tres líneas semicirculares. Medidas: diámetro de la boca: $14,6 \mathrm{~cm}$, diámetro de la base $23 \mathrm{~cm}$; altura: $35,6 \mathrm{~cm}$.

$\mathrm{n}^{\circ}$ 2: TSHB. Forma 15. Jarra de cuerpo globular, base plana, cuello estrecho, boca con concavidad interna, asa de cinta. Pasta blanquecina, tamizada; al exterior engobe amarillentodorado, de brillo muy perdido. Medidas: diámetro de la boca: $5,7 \mathrm{~cm}$, diámetro de la base: $7,2 \mathrm{~cm}$, altura: $29,7 \mathrm{~cm}$.

$\mathrm{n}^{\circ}$ 3: Cerámica fina inclasificable. Pared de una vasija globular; barro decantado de color gris ceniciento, más oscuro en la zona de la base, superficie externa alisada. Decoración: a ruedecilla, friso delimitado en la parte superior por acanaladuras, bajo él cuadrados impresos en sentido horizontal. Medidas: diámetro máximo: $18 \mathrm{~cm}$, altura conservada: $17 \mathrm{~cm}$.

$\mathrm{n}^{\circ}$ 4: Cerámica común. Olla de perfil ovoide y borde de sección triangular. El color de la pasta oscila entre ocre-amarillento y gris. Cocción reductora. Borde y pared ahumados. Medidas: diámetro de la boca: $13,2 \mathrm{~cm}$, diámetro de la base: $58 \mathrm{~cm}$, altura: $14,5 \mathrm{~cm}$.

$n^{\circ}$ 5: Cerámica común. Olla de perfil ovoide. Borde exvasado y almendrado que cuelga respecto al cuello, dejando una concavidad al interior. Fondo umbicular. Pasta negra con desgrasantes de cuarzo, caliza y mica. Medidas: diámetro de la boca: $15 \mathrm{~cm}$, diámetro de la base: $8,8 \mathrm{~cm}$, altura: $20,1 \mathrm{~cm}$.

\section{Figura 17}

$\mathrm{n}^{\circ}$ 1: cc. Olla de perfil globular. Borde vuelto y engrosado, con una concavidad al interior. Pasta de color ocre-gris con desgrasante micáceo. Bor-de y pared ahumados. Medi- 
das: diámetro de la boca: $17,4 \mathrm{~cm}$, diámetro de la base: 9,3 $\mathrm{cm}$, altura: $21,6 \mathrm{~cm}$.

$\mathrm{n}^{\mathrm{o}}$ 2: cc. Olla de perfil ovoide con borde oblicuo almendrado. Acanaladura en la parte superior de la pared. Pasta de color gris oscuro. Medidas: diámetro de la boca: $12 \mathrm{~cm}$, diámetro de la base: $5,1 \mathrm{~cm}$, altura: $15,3 \mathrm{~cm}$.

$\mathrm{n}^{\circ}$ 3: cc. Olla con el borde recorrido por acanaladura al exterior y cóncavo al interior. Pasta gris. Cocción reductora. Ambas superficies quemadas. Medidas: diámetro de la boca: $16 \mathrm{~cm}$, diámetro de la base: $8,2 \mathrm{~cm}$, altura: $20,5 \mathrm{~cm}$.

$\mathrm{n}^{\circ}$ 4: cc. Tercio superior de una olla con borde de sección triangular, pero recorrido por una acanaladura longitudinal en su parte externa. Pasta gris. Superficie ahumada. Medidas: diámetro de la boca: $15 \mathrm{~cm}$, altura conservada: $7 \mathrm{~cm}$.

$\mathrm{n}^{\circ}$ 5: cc. Olla de perfil ovoide con borde oblicuo engrosado. Pasta de color ocre-gris con desgrasante micáceo. Medidas: diámetro de la boca: $12,2 \mathrm{~cm}$, diámetro de la base: 6,3 $\mathrm{cm}$, altura: $14,7 \mathrm{~cm}$.

$\mathrm{n}^{\circ}$ 6: cc. Cubierta del vaso pintado no 1 de la Lám. III. Está realizado con la parte inferior de un recipiente de cerámica común de pasta gris. Presenta un grafito en forma de aspa al exterior del fondo. Medidas: diámetro de la base: $8,5 \mathrm{~cm}$.

$\mathrm{n}^{\circ}$ 7: cc. Fondo de un vaso. Medidas: diámetro de la base: $6 \mathrm{~cm}$.

\section{FIGURA 18}

$\mathrm{n}^{\circ}$ 1: cc. Olla de perfil globular. Borde exvasado. Medidas: diámetro de la boca: $12,2 \mathrm{~cm}$, diámetro de la base: $8,5 \mathrm{~cm}$, altura: $15,1 \mathrm{~cm}$.

$\mathrm{n}^{\circ}$ 2: cc. Olla de perfil globular. Borde exvasado. Medidas: diámetro de la boca: $12,2 \mathrm{~cm}$, diámetro de la base: $9 \mathrm{~cm}$, altura: $15,8 \mathrm{~cm}$.

$\mathrm{n}^{\circ}$ 3: cc. Plato de pared oblicua y borde entrante. Pasta ocre-amarillenta con abundantes desgrasantes micáceos. Medidas: diámetro de la boca: $21,8 \mathrm{~cm}$, diámetro de la base: $18,5 \mathrm{~cm}$, altura: $4,1 \mathrm{~cm}$. Sobre el borde tiene cinco rayas incisas, dos de ellas dobles a intervalos más o menos regulares que marcan la división del perímetro en 5 porciones. Ahumado al exterior.

$\mathrm{n}^{\circ}$ 4. CC. Plato de pared oblicua, fondo plano y borde en forma de bastoncillo. Pasta gris muy micácea. Fondo y pared externa muy ahumados. Medidas: diámetro de la boca: 26,2 $\mathrm{cm}$, diámetro de la base: $22,2 \mathrm{~cm}$, altura: $4 \mathrm{~cm}$.

$\mathrm{n}^{\circ}$ 5: cc. Gran plato de pared curva, borde entrante sin labio y fondo plano, forma Hayes 181. Pasta ocre-rosada, bastante desgrasante de mica. Presenta ambas superficies quemadas. Grafitos: T VAL T con nexo cuádruple, y tres rayas paralelas horizontales al interior. Al exterior en el fondo y no centradas, varias rayas en haz, algunas más cortas. En el borde presenta a intervalos regulares y de forma radial cinco cortos trazos incisos que dividen el perímetro en cinco sectores. Uno de los trazos es doble. Medidas: diámetro de la boca: $36,3 \mathrm{~cm}$, diámetro de la base: $31,5 \mathrm{~cm}$, altura: $5,5 \mathrm{~cm}$. Ahumado al exterior.

$\mathrm{n}^{\circ}$ 6: cc. Vasito piriforme con la base plana muy estrecha y el borde saliente de sección triangular. Pasta negra con desgrasantes de mica y algunos cristales de cuarzo de gran tamaño. Medidas: diámetro de la boca: $9,3 \mathrm{~cm}$, diámetro de la base: $3,4 \mathrm{~cm}$, altura: $8 \mathrm{~cm}$.

$\mathrm{n}^{\circ}$ 7: cc. Vasito piriforme con la base plana muy estrecha y el borde saliente de sección plana. Pasta negra, con desgrasantes de mica y algunos cristales de cuarzo de gran tamaño. Medidas: diámetro de la boca: 9,4 cm, diámetro de la base: 3 , $1 \mathrm{~cm}$, altura: $9 \mathrm{~cm}$.

$\mathrm{n}^{\circ}$ 8: CC. Mortero. Forma Dramont D2, con borde horizontal y base plana ligeramente resaltada mediante una acanaladura. Pasta ocre-rosa con abundantes desgrasantes de cuarzo y algunos de mica. Medidas: diámetro de la boca: $29,2 \mathrm{~cm}$, diámetro de la base: $14,6 \mathrm{~cm}$, altura: $7,9 \mathrm{~cm}$.

\section{Figura 19}

$\mathrm{n}^{\mathrm{o}}$ 1: Ánfora. Varios fragmentos de la boca, carena, asas geminadas y pivote de un ánfora Dressel 2/4. El color de la pasta oscila entre marrón y gris. Sobre la zona del pivote presenta un grafito en forma de $\mathrm{C}$ invertida. Medidas: diámetro de la boca: $16,2 \mathrm{~cm}$.

$\mathrm{n}^{\circ}$ 2: Ánfora. Boca y arranque de las asas de un ánfora de salazón de pasta grosera ocre con calcita, cuarzo y algo de mica. Medidas: diámetro de la boca: $18,2 \mathrm{~cm}$.

$\mathrm{n}^{\circ}$ 3: Cerámica común de tradición local de pasta beige de textura fina. Boca, cuello y asa de cinta de un olpe o cántaro de proporciones grandes: desde el borde a la base del asa tiene $23 \mathrm{~cm}$ de altura por lo que la altura total se podría calcular en algo más de $55 \mathrm{~cm}$ El asa es acanalada, decorada con botones aplicados. Pasta beige. Medidas: diámetro de la boca: $9 \mathrm{~cm}$.

\section{FIGURA 20}

$\mathrm{n}^{\mathrm{o}}$ 1: Hoz de hierro. Hoja de sección triangular de $3 \mathrm{~cm}$ de anchura. En el extremo se conserva parte del mango de madera.

$\mathrm{n}^{\mathrm{o}}$ 2: Fragmento de hierro de paletón de llave. Pieza de sección cuadrada.

$\mathrm{n}^{\circ}$ 3: Anillo de bronce de delgada sección y $1,7 \mathrm{~cm}$ de diámetro con una hoja alargada nervada, grabada en el fino chatón.

$\mathrm{n}^{\circ}$ 4: Punzón de hierro de punta incompleta con sección cuadrada y $1,2 \mathrm{~cm}$ de anchura. Longitud $8,9 \mathrm{~cm}$; mango de hueso de sección circular de $1,5 \mathrm{~cm}$ de diámetro.

$\mathrm{n}^{\circ}$ 5: Bisagra de hueso. Pieza cilíndrica realizada sobre hueso de 2,5 cm de ancho, presenta un orificio circular.

$\mathrm{n}^{\circ}$ 6. Pequeño instrumento de bronce (¿pequeño trípode?) con una zona central plana circular e incompleta de $2,5 \mathrm{~cm}$ de diámetro, de la que salen dos apéndices (pudo tener un tercero) de sección circular y rotos en el extremo. Altura aproximada: $3,2 \mathrm{~cm}$.

$\mathrm{n}^{\circ}$ 7: Cuchillo de hierro con hoja de filo curvo y sección triangular $(2,7 \mathrm{~cm}$ de anchura máxima) Longitud: $20 \mathrm{~cm}$; mango de hueso de sección ovalada 2 por $2,3 \mathrm{~cm}$.

$\mathrm{n}^{\circ}$ 8: Vidrio. Fragmento de borde horizontal de color blanquecino. Medidas: diámetro de la boca: $8,3 \mathrm{~cm}$.

$\mathrm{n}^{\circ}$ 9: Vidrio. Forma Isings 45. Fragmento de borde tubular de color verde claro. Medidas: diámetro de la boca: $6,7 \mathrm{~cm}$. $\mathrm{n}^{\circ}$ 10: Vidrio. Fragmento de fondo umbilicado. Color verdoso. Medidas: diámetro de la base: $4 \mathrm{~cm}$.

$\mathrm{n}^{\circ}$ 11: Vidrio. Fragmento de pared decorada con finos baquetones. Color blanquecino..

$\mathrm{n}^{\mathrm{o}}$ 12: Vidrio. Fragmento del perfil carenado con un fino baquetón de color blanquecino.

$n^{\circ}$ 13: Vidrio. Fragmento de base plana. de color blanquecino. Medidas: diámetro de la base: $4,2 \mathrm{~cm}$.

\section{BIBLIOGRAFÍA}

Abascal Palazón, J. M. 1986a: La cerámica pintada romana de tradición indígena en la península ibérica. Centros de producción, comercio y tipología. Madrid.

Abascal Palazón, J. M. 1986b: «Un probable taller local de cerámica pintada tardorromana en Tarancueña (Soria)». Lucentum V, 137-145.

Abascal Palazón, J. M. 1988: «Olpes pintados de 
Época Imperial en la provincia de Alicante». Saguntum 21 1987-88, 361-377.

Abascal Palazón, J. M.; Cebrián Fernández, R. 2007: «Grafitos cerámicos de Segobriga (1997-2006)». Lucentum XXVI, 127-171.

Aguarod Otal, M. C. 1985: «Avance al estudio de un posible alfar romano en Tarazona IV: La cerámica común». Turiaso VI. 21-62.

Aguarod Otal, M. C. 1991: Cerámica romana importada de cocina en la Tarraconense. Zaragoza.

Alarcão J.; Alarco, A. 1966: «O espólio da necrópole luso-romana de Valdoca (Aljustrel)». Conimbriga VI, 7-104.

Alarcão J. 1974: «A necrópole do Monte do Farrobo (Aljustrel)» Conimbriga. XIII, 5-32.

Alarcão J. 1975: Fouilles de Conimbriga V. La céramique commune locale et régionale. Paris.

Alarcão J.; Delgado, M.; Mayet, F.; Moutinho, A.; Ponte, S. 1976: Fouilles de Conimbriga VI. Céramiques diverses et verres. Paris.

Allison, P. M. 2004: Pompeian Household. An analisis of the material culture. Cotsen Institut of Archaeology Monographs 42. University of California. Los Angeles.

Argente Oliver, J. L.; Argente, I.; De la Casa, C.; Fernández, V.; González, A.; Teres, E. 1984: Tiermes II. Campañas de 1979 y 1980. EAE 128. Madrid.

Argente, J. L.; Díaz Díaz, A. et alii 1994: Tiermes IV. La casa del Acueducto. EAE 167. Madrid.

Arrizabalaga, A.; Pérez, E. 1994: «Oleoducto Zaragoza-Pamplona-Ribavellosa. Yacimiento de Puente de Arce» Arqueología de urgencia en Álava 1989-1993. Vitoria, 113-120.

Béal, J. C. 1983: Catalogue des objets de tabletterie du Musée de la Civilisation gallo-romaine de Lyon. Lyon.

Beltrán, M.; Paz, J. A. 2004: «Las aguas sagradas del municipium Turiaso. Excavaciones en el patio del Colegio Joaquín Costa (Antiguo Allúe Salvador). Tarazona (Zaragoza)». Caesaraugusta 76, 33-258.

Bonnet, C. et alii 2006: «Evolution des céramiques de la fin du $\mathrm{II}^{\mathrm{e}}$ s. au V $\mathrm{V}^{\mathrm{e}}$ s. apud J. C. dans la Drôme: l'exemple de Bourbousson (Crest) sur le tracé du TGV Méditerranée». RANarb 38-39, 2005 2006, 483-506.

Burillo, F. 1981: «Poblado de San Esteban. El Poyo del Cid (Teruel)». NAH 12, 189-275.

Caballero Zoreda, L. (ed.) 1992: Arcóbriga II. Las cerámicas romanas. Zaragoza.

Caballero Zoreda, L.; Juan Tovar, L. C. 1984: «Terra Sigillata Hispánica Brillante». Ampurias 4546 (1983-1984), 154-193.
Casa Martínez, C. De La; Domenech Esteban, M.; Izquierdo Bértiz, J. Mª ; Jimeno Martínez, A.; Revilla Andía, M ${ }^{\mathrm{a}}$ L. 1994: Tiermes III. Campañas de 1981-1984. Excavaciones realizadas en la ciudad romana y en las necrópolis medievales. EAE 166. Madrid.

Castañer i Masoliver, P.; Tremoleda i Trilla J.; Roure i Bonaventura, A. 1990: «Un conjunt ceràmic de finals del segle III d. C. a Vil-1-auba (Camós, Pla de L'Estany)». Cypsela VIII, 157-191.

Comas i Solá, M. 1985: Baetulo, les anfores. Badalona.

Cool, H. E. M. 2006: Eating and drinking in Roman Britain. Cambridge.

Delgado, M.; Mayet, F.; Mutinho De Alarcao, A. 1975: Fouilles de Conimbriga IV. Les sigillées. Paris.

Degbomont, J. M. 1984: Le chauffage par hipocauste dans l'habitat privé. De la place Lambert a l'Aula Palatina. Herault 17. Liège.

Domergue, P.; Martin Th. 1977: Minas romanas en la Provincia de León. EAE 94. Madrid.

Escrivá Torres, V. 1989: Cerámica romana de Valencia. La Terra Sigillata Hispánica. Valencia.

Evans, J. 1993: «Pottery function and finewares in the Roman north». Journal of Roman Pottery Studies 6, 95-118.

Fernández Izquierdo, A. 1984: Las ánforas romanas de Valentia y de su entorno marítimo. Valencia.

Flos Travieso, N. 1987: Baetulo. Els vidres. Monografíes badalonines 10 .

García Merino, C. 1990: «Nuevas piezas de la artesanía romana del bronce en la Meseta: apliques con gorgoneion y candelabrum de Uxama». BSAA LVI, 244-257.

García Merino, C. 1991: «La casa urbana en Uxama Argaela». La casa urbana hispanorromana. Ponencias y comunicaciones. Zaragoza, 233-259.

García Merino, C. 1995 a: Uxama I. Campañas de 1976 y 1978. EAE 170. Madrid.

García Merino, C. 1995 b: «Materiales numismáticos de las excavaciones de la Casa de los plintos de Uxama». La moneda hispánica. Ciudad y territorio, $\mathrm{M}^{\mathrm{a}}$ P. García-Bellido; Rui Manuel Sobral Centeno (eds.). Anejos de AEspA XIV, 191-198.

García Merino, C. 1997: «La vieja Uxama». La ciudad de seis pisos. Catálogo de la exposición Las Edades del Hombre. (Burgo de Osma, Soria). Madrid, Cap. I, 79-108.

García Merino, C.; Sánchez Simón, M. 1996: «Enterramiento infantil bajo un pavimento de la Casa de los plintos de Uxama». Celtiberia 90, 203-214. García Merino, C.; Sánchez Simón, M.; Burón Ál- 
varez, M. 2007: «Pinturas de la Casa de los Plintos de Uxama». Circulación de temas y sistemas decorativos en la pintura mural antigua. (C. Guiral ed.) Actas del IX Congreso Internacional de la AIPMA. Zaragoza, 447-450

García Merino, C.; Sánchez Simón, M.; Burón Álvarez, M. 2008: «Un depósito cerrado del siglo III: La habitación 7 de la casa de los plintos de Uxama (Osma, Soria)» S.F.E.C.A.G. (Societé Française d'Etudes de la Céramique Antique en Gaule) Actas del Congrès de l'Escala-Empúries (1-4 Mai 2008). Marseille, 277-280.

Gillani, G.; Vancetti, R.; García Merino, C. 1994: «La Casa de los plintos de Uxama y su restitución por ordenador». Revista de Arqueología 160, 6-13

Gurt Esparraguera, J. Ma 1985: Clunia III. Hallazgos monetarios. La romanización de la Meseta norte a través de la circulación monetaria de la ciudad de Clunia. EAE 145.

Isings, C. 1957: Roman glass from dated finds. Archaeologica Traiectina, II. Groningen-Djakarta.

Juan Tovar, L. C. 2000: «La terra sigillata de Quintanilla de la Cueza». M. A. García Guinea (dir.): La villa romana de Quintanilla de la Cueza ( $\mathrm{Pa}$ lencia). Memoria de las excavaciones 1970-1981. Palencia. X, 211-216.

Leblanc, O.; Desbat, A. 1992: «Un lot de céramiques du début du III $^{\mathrm{e}}$ siècle à Saint-Romain-en- Gal (Rhône)». RANarb 25, 125-150.

Llorens, M ${ }^{\text {a }}$ Del M.; Ripollés, P. P. 1995: «El depósito monetal de la domus A de Romeu: nuevas aportaciones a la circulación de moneda de bronce en Saguntum durante el siglo III d. C.» Saguntum 28, 217-228.

López, M.; Chiner, P. 1994: «Noticia preliminar de las excavaciones de la domus tardía del solar de Romeu (Sagunto)». Saguntum 27, 229-237.

Mayet, F. 1984: Les céramiques sigillées hispaniques. Paris.

Mezquíriz, Ma A. 1961: Terra Sigillata Hispánica. Madrid.

Mezquíriz, Ma A. 1978: Pompaelo II. Pamplona.

Mezquíriz, M ${ }^{\mathrm{a}}$ A. 1985: Terra Sigillata Ispanica. Roma

Millett, M. 1979: «An approach to the funcional interpretation of pottery» en Millet, M. (ed). Pottery and the Archeologist. London, 35-47.

Ona, J. L.; Paz Peralta, J. A.; Pérez Casas, J. A.; De Sus, M ${ }^{a}$ L. 1987: Arqueología urbana en Jaca. El solar de los Escolapios. Zaragoza.

Paz Peralta, J. A. 1991: Cerámica de mesa romana de los s. III al vi d. C. en la provincia de Zaragoza. Zaragoza.
Palol, P. de; Cortes, J. 1974: La villa romana de la Olmeda, Pedrosa de la Vega (Palencia). Excavaciones de 1969-1970. Acta Arqueológica Hispánica, VII. Madrid.

Palol, P. de; Guitart, J. 2000: Clunia viII. 1. Los grandes conjuntos públicos. El foro colonial de Clunia. Salamanca

Peacock, D. P. S.; William, D. 1986: Amphorae and the Roman economy. New York.

Romero Carnicero, M ${ }^{a}$ V. 1985: Numancia I. La Terra Sigillata. EAE, 146. Madrid.

Romero Carnicero, $\mathrm{M}^{\mathrm{a}} \mathrm{V}$.; Tarancón Gómez, M $\mathrm{M}^{\mathrm{a}} \mathrm{J}$; Arellano Hernández, O.; Barrio Onrubia, R.; Lerín Sanz, M.; Ruiz De Marco, A. 2008: «El centro de producción cerámica de Uxama (Osma/ El Burgo de Osma, Soria)». S.F.E.C.A.G. (Societé Française d'Etudes de la Céramique Antique en Gaule). Actas del Congrès de l'Escala-Empúries (1-4 Mai 2008). Marseille, 319330 .

Roure, A.; Tremoleda, J.; Castanyer, P. 1989: «Troballa d'un conjunt monetari a Villauba (Camós, Pla de L’Estany)». Empúries 48-50, 1986-89, págs. 268-281.

Sánchez-Lafuente, J. 1990: Terra sigillata de Segobriga y las ciudades de su entorno: Valeria, Ercavica y Complutum. Madrid.

Sánchez-Lafuente, J. 1991: «Grafitos sobre instrumental doméstico en sigillata de Segóbriga y su entorno». Hispania Antiqua XV, 1-32.

Sánchez-Lafuente, J.; Polo López, J.; Rascón Marqués, S. 1999: «Grafitos sobre instrumental doméstico en Hispania. Problemas y perspectivas de estudio». Actas del IX Congresso Internazionale di Epigrafía greca e latina. Roma, 585-599.

Tuset i Bertrán, F.; Buxeda i Garrigós, J. 1995: «La cerámica terra sigillata hispanica avanzada (TSHA) de Clunia: segunda mitad del s. II- s. III d. C.» I Congreso de Arqueología Peninsular. Porto, 12-18 de Octubre 1993. Porto. Vol. V, 355367.

Vegas, M. 1973: Cerámica común romana del mediterráneo occidental. Barcelona.

Vidal, M.; Miguel, L. E. de 1988: «El abandono de una casa romana en Cartagena (solar C/ Cuatro Santos, $\mathrm{n}^{\circ}$ 40)». Arte y poblamiento en el sureste peninsular. Antigüedad y cristianismo. Monografía histórica sobre la Antigüedad tardía, V. Murcia, 435-448.

VV.AA. 2008: The countryside at the 3rd century. From Septimius Severus to the Tetrarchy. Studies on the rural world in the Roman Period 3. Universitat de Girona. Girona. 


\section{APÉNDICE}

Incluimos la relación completa de los materiales hallados en la habitación 7 de la Casa de los plintos en el depósito producido durante el incendio que destruyó definitivamente el edificio por ser interesante la cuantificación y la asociación de unos y otros.

- Terra sigillata hispánica (vajilla de mesa): 17 piezas completas:

9 cuencos (1 hisp. 27 evolucionado y 8 hisp. 8 de diferentes tamaños entre 23,8 y $10 \mathrm{~cm}$ de diámetro: 4 grandes, 1 mediano y 3 pequeños)

3 platos $15 / 17$

2 vasitos de perfil troncocónico de paredes oblicuas, variante de la D. 33

1 jarra hisp. 21.

- Cerámica pintada de tradición (de mesa y almacenamiento): 17 piezas:

9 vasos carenados Abascal 3 a evolucionada,

1 vaso carenado Abascal $3 \mathrm{~b}$

2 vasos bitroncocónicos con dos asas, Abascal 23

1 olpe

1 orza globular

1 ollita

1 dolio

1 gran jarra con dos asas tapada con media olla de cerámica común.

- Cerámica común de tradición (almacenamiento): 1 pieza: parte superior de una botella con asa decorada con pastillas

- Cerámica común (culinaria y de almacenamiento): 25 piezas (21 completas):

5 platos-fuentes para guisar (¿y servir?)

13 ollas de tres tamaños diferentes entre 17 y 13 cm diámetro: 6 grandes 3 medianas y 4 pequeñas)

3 vasitos piriformes o pucheritos,

1 mortero
- Ánforas

-2 ánforas (una vinaria y otra de salazón) ( y) varios fragmentos de otra.

- Terra sigillata hispánica brillante: 1 jarra.

- Otras cerámicas: 1 jarra gris con reticulado.

- Terracota:

10 pesas de telar tras la puerta del patio entre carbón de enebro, de ellas 2 de 1 k, 6 de 200 grs y 1 de 150 gr.

4 fichas de 7 y $10 \mathrm{~cm}$ diámetro.

- Hierro: 1 cuchillo con mango de hueso, 1 lezna con mango de hueso, partes de una llave, 2 bisagras, 1 aldabilla, varios clavos de muebles o de la puerta y el telar.

- Bronce: 1 anillo con mesa decorada con una hoja nervada y un fragmento de plancha de plomo doblado

- Vidrio: 1 cuenta de collar, varios fragmentos de diferentes recipientes de vidrio, azul, blanco y verde de formas pequeñas cuencos para beber y un fragmento de 1 cuenco azul.

- Hueso: 1 bisagra y 2 acus crinales.

- Muebles:

1 armario o baldas de enebro y restos de pigmento azul al pie de la pared $\mathrm{N}$.

1 mesita o tajo de carnicero

un posible telar

maderas y herrajes de puertas y ventana

- Restos de comida: 1 vieira, huesos de cordero o cabra, conejo, cerdo o jabalí, y cérvido

- Material numismático:

1 as de Segobrix

1 as de Vespasiano

1 sestercio de Trajano

1 sestercio de Antonino Pio muy desgastado, que se encontraba bajo un vaso carenado.

1 tésera con resello de cabeza de águila. 